University of Nebraska - Lincoln

DigitalCommons@University of Nebraska - Lincoln

Papers in the Earth and Atmospheric Sciences Earth and Atmospheric Sciences, Department

2009

\title{
Obliquity-paced Pliocene West Antarctic ice sheet oscillations
}

\author{
T. Naish \\ Victoria University of Wellington \\ R. D. Powell \\ Northern Illinois University, ross@geol.niu.edu \\ R. Levy \\ University of Nebraska-Lincoln \\ G. Wilson \\ University of Otago \\ R. Scherer \\ Northern Illinois University
}

See next page for additional authors

Follow this and additional works at: https://digitalcommons.unl.edu/geosciencefacpub

Part of the Earth Sciences Commons

Naish, T.; Powell, R. D.; Levy, R.; Wilson, G.; Scherer, R.; Talarico, F.; Krissek, L.; Niessen, F.; Pompilio, M.; Wilson, T. J.; Carter, L.; DeConto, R.; Huybers, P.; McKay, R.; Pollard, D.; Ross, J.; Winter, D.; Barrett, P.; Browne, G.; Cody, R.; Cowan, E. A.; Crampton, J.; Dunbar, G.; Dunbar, N.; Florindo, F.; Gebhardt, C.; Graham, I.; Hannah, M.; Hansaraj, D.; Harwood, David M.; Helling, D.; Henrys, S.; Hinnov, L.; Kuhn, G.; Kyle, P.; La"ufer, A.; Maffioli, P.; Magens, D.; Mandernack, K.; McIntosh, W.; Millan, C.; Morin, R.; Ohneiser, C.; Paulsen, T.; Persico, D.; Raine, I.; Reed, J.; Riesselman, C.; Sagnotti, L.; Schmitt, D.; Sjunneskog, C.; Strong, P.; Taviani, M.; Vogel, S.; Wilch, T.; and Williams, T., "Obliquity-paced Pliocene West Antarctic ice sheet oscillations" (2009). Papers in the Earth and Atmospheric Sciences. 185.

https://digitalcommons.unl.edu/geosciencefacpub/185

This Article is brought to you for free and open access by the Earth and Atmospheric Sciences, Department of at DigitalCommons@University of Nebraska - Lincoln. It has been accepted for inclusion in Papers in the Earth and Atmospheric Sciences by an authorized administrator of DigitalCommons@University of Nebraska - Lincoln. 


\section{Authors}

T. Naish, R. D. Powell, R. Levy, G. Wilson, R. Scherer, F. Talarico, L. Krissek, F. Niessen, M. Pompilio, T. J. Wilson, L. Carter, R. DeConto, P. Huybers, R. McKay, D. Pollard, J. Ross, D. Winter, P. Barrett, G. Browne, R. Cody, E. A. Cowan, J. Crampton, G. Dunbar, N. Dunbar, F. Florindo, C. Gebhardt, I. Graham, M. Hannah, D. Hansaraj, David M. Harwood, D. Helling, S. Henrys, L. Hinnov, G. Kuhn, P. Kyle, A. La“ufer, P. Maffioli, D. Magens, K. Mandernack, W. McIntosh, C. Millan, R. Morin, C. Ohneiser, T. Paulsen, D. Persico, I. Raine, J. Reed, C. Riesselman, L. Sagnotti, D. Schmitt, C. Sjunneskog, P. Strong, M. Taviani, S. Vogel, T. Wilch, and T. Williams 


\title{
Obliquity-paced Pliocene West Antarctic ice sheet oscillations
}

\author{
T. Naish ${ }^{1,2}$, R. Powell ${ }^{3}$, R. Levy ${ }^{4} \dagger$, G. Wilson ${ }^{5}$, R. Scherer ${ }^{3}$, F. Talarico ${ }^{6}$, L. Krissek ${ }^{7}$, F. Niessen ${ }^{8}$, M. Pompilio $^{9}$, \\ T. Wilson ${ }^{7}$, L. Carter ${ }^{1}$, R. DeConto ${ }^{10}$, P. Huybers ${ }^{11}$, R. McKay ${ }^{1}$, D. Pollard ${ }^{12}$, J. Ross ${ }^{13}$, D. Winter ${ }^{4}$, P. Barrett ${ }^{1}$, \\ G. Browne ${ }^{2}$, R. Cody ${ }^{1,2}$, E. Cowan ${ }^{14}$, J. Crampton ${ }^{2}$, G. Dunbar ${ }^{1}$, N. Dunbar ${ }^{13}$, F. Florindo ${ }^{15}$, C. Gebhardt ${ }^{8}$, I. Graham $^{2}$, \\ M. Hannah ${ }^{1}$, D. Hansaraj ${ }^{1,2}$, D. Harwood ${ }^{4}$, D. Helling ${ }^{8}$, S. Henrys ${ }^{2}$, L. Hinnov ${ }^{16}$, G. Kuhn ${ }^{8}$, P. Kyle ${ }^{13}$, A. Läufer $^{17}$, \\ P. Maffioli ${ }^{18}$, D. Magens ${ }^{8}$, K. Mandernack ${ }^{19}$, W. Mclntosh ${ }^{13}$, C. Millan ${ }^{7}$, R. Morin ${ }^{20}$, C. Ohneiser ${ }^{5}$, T. Paulsen ${ }^{21}$, \\ D. Persico ${ }^{22}$, I. Raine ${ }^{2}$, J. Reed ${ }^{23,4}$, C. Riesselman ${ }^{24}$, L. Sagnotti ${ }^{15}$, D. Schmitt ${ }^{25}$, C. Sjunneskog ${ }^{26}$, P. Strong ${ }^{2}$, \\ M. Taviani ${ }^{27}$, S. Vogel ${ }^{3}$, T. Wilch $^{28} \&$ T. Williams ${ }^{29}$
}

Thirty years after oxygen isotope records from microfossils deposited in ocean sediments confirmed the hypothesis that variations in the Earth's orbital geometry control the ice ages ${ }^{1}$, fundamental questions remain over the response of the Antarctic ice sheets to orbital cycles ${ }^{2}$. Furthermore, an understanding of the behaviour of the marinebased West Antarctic ice sheet (WAIS) during the 'warmerthan-present' early-Pliocene epoch ( 5-3 Myr ago) is needed to better constrain the possible range of ice-sheet behaviour in the context of future global warming ${ }^{3}$. Here we present a marine glacial record from the upper $600 \mathrm{~m}$ of the AND-1B sediment core recovered from beneath the northwest part of the Ross ice shelf by the ANDRILL programme and demonstrate well-dated, $\sim 40-\mathrm{kyr}$ cyclic variations in ice-sheet extent linked to cycles in insolation influenced by changes in the Earth's axial tilt (obliquity) during the Pliocene. Our data provide direct evidence for orbitally induced oscillations in the WAIS, which periodically collapsed, resulting in a switch from grounded ice, or ice shelves, to open waters in the Ross embayment when planetary temperatures were up to $\sim 3{ }^{\circ} \mathrm{C}$ warmer than today ${ }^{4}$ and atmospheric $\mathrm{CO}_{2}$ concentration was as high as $\sim 400$ p.p.m.v. (refs 5,6$)$. The evidence is consistent with a new ice-sheet/ice-shelf model $^{7}$ that simulates fluctuations in Antarctic ice volume of up to $+7 \mathrm{~m}$ in equivalent sea level associated with the loss of the WAIS and up to $+3 \mathrm{~m}$ in equivalent sea level from the East Antarctic ice sheet, in response to ocean-induced melting paced by obliquity. During interglacial times, diatomaceous sediments indicate high surface-water productivity, minimal summer sea ice and air temperatures above freezing, suggesting an additional influence of surface melt ${ }^{8}$ under conditions of elevated $\mathrm{CO}_{2}$.
The Earth's climate system during the Pliocene and earlyPleistocene epochs was regulated by a $\sim 40$-kyr periodicity. The geological evidence for this is widespread and expressed in polar to equatorial depositional environments including (1) ice volume from oxygen isotope $\left(\delta^{18} \mathrm{O}\right)$ records, that co-vary with the pattern of icerafted debris in deep-sea sediments ${ }^{9}$; $(2)$ ocean circulation ${ }^{10}$ and temperature also inferred from deep-sea sediment proxies $^{11,12}$; (3) atmospheric circulation from continental dust deposits ${ }^{13}$; and (4) global sea-level fluctuations recorded in the shallow-marine continental margins $^{14}$.

The 40-kyr cycle is almost certainly linked to variations in the Earth's orbital obliquity. However, the specific nature of this forcing and its influence on Antarctic glaciation remain unresolved owing to a lack of well-dated climate records that directly sample past oscillations of the ice sheet. The new AND-1B core provides such a record (Fig. 1). In this Letter, we focus on the early Pliocene ( $~ 5-3 \mathrm{Myr}$ ago $)$ part of the record, because for this period the response of Antarctic ice sheets to orbital forcing can be studied without the complicating influence of large Northern Hemisphere ice sheets on sea-level and deep-sea $\delta^{18} \mathrm{O}$ records ${ }^{15}$. Furthermore, polar ice-sheet boundary conditions were similar to today, but the climate was warmer ${ }^{3,5,6}$. With anthropogenic warming projected to rise an average of $\sim 3{ }^{\circ} \mathrm{C}$ in mean temperature by the end of the twenty-first century, more significance is being placed on the early Pliocene as an analogue for understanding the future behaviour of the WAIS ${ }^{3}$ and its contribution to global sea level ${ }^{16}$. Far-field geological evidence for palaeoshorelines up to $25 \mathrm{~m}$ above present ${ }^{17,18}$ are consistent with ice-volume estimates from deep-ocean $\delta^{18} \mathrm{O}$ data ${ }^{19}$, and imply deglaciation of the Greenland ice sheet, the

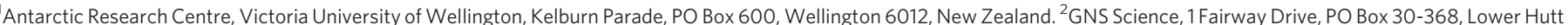
5040, New Zealand. ${ }^{3}$ Department of Geology \& Environmental Geosciences, Northern Illinois University, DeKalb, Illinois 60115, USA. ${ }^{4}$ ANDRILL Science Management Office,

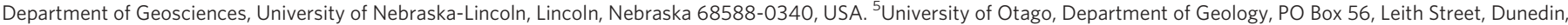

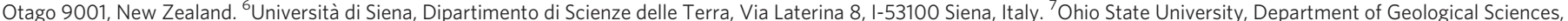

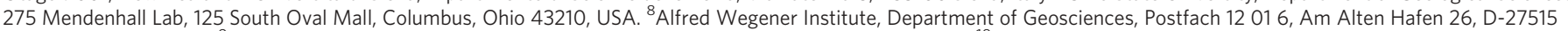

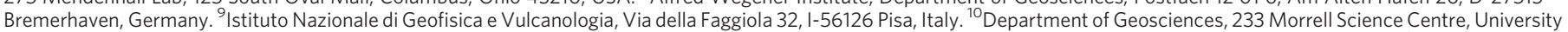
of Massachusetts, Amherst, Massachusetts 01003-9297, USA. ${ }^{11}$ Department of Earth and Planetary Sciences, Harvard University, Massachusetts 02138, USA. ${ }^{12}$ Earth and

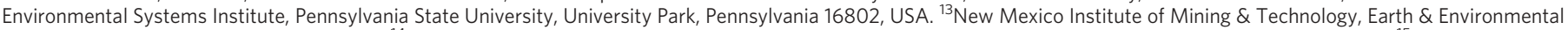

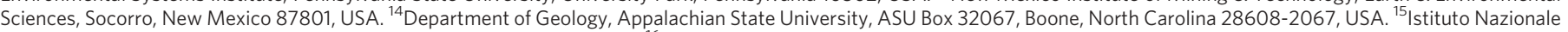

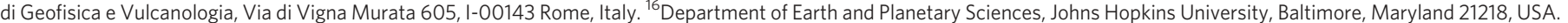
${ }^{17}$ Federal Institute of Geosciences \& Natural Resources, BGR, Stilleweg 2, D-30655 Hannover, Germany. ${ }^{18}$ Università Milano-Bicocca, Dipartimento di Scienze Geologiche e

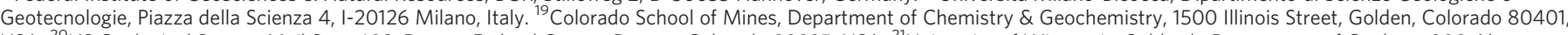

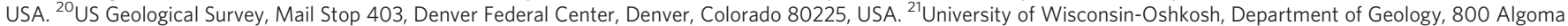

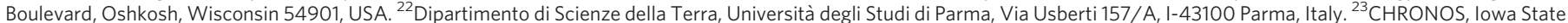

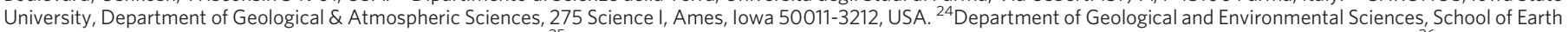

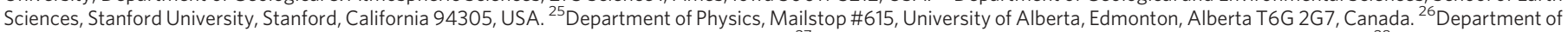
Geology and Geophysics, Louisiana State University, Baton Rouge, Louisiana 70803, USA. ${ }^{27}$ CNR, ISMAR - Bologna, Via Gobetti 101 , I-40129 Bologna, Italy. ${ }^{28}$ Albion College,

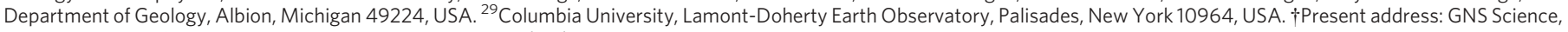
1 Fairway Drive, PO Box 30368, Lower Hutt 5040, New Zealand. 


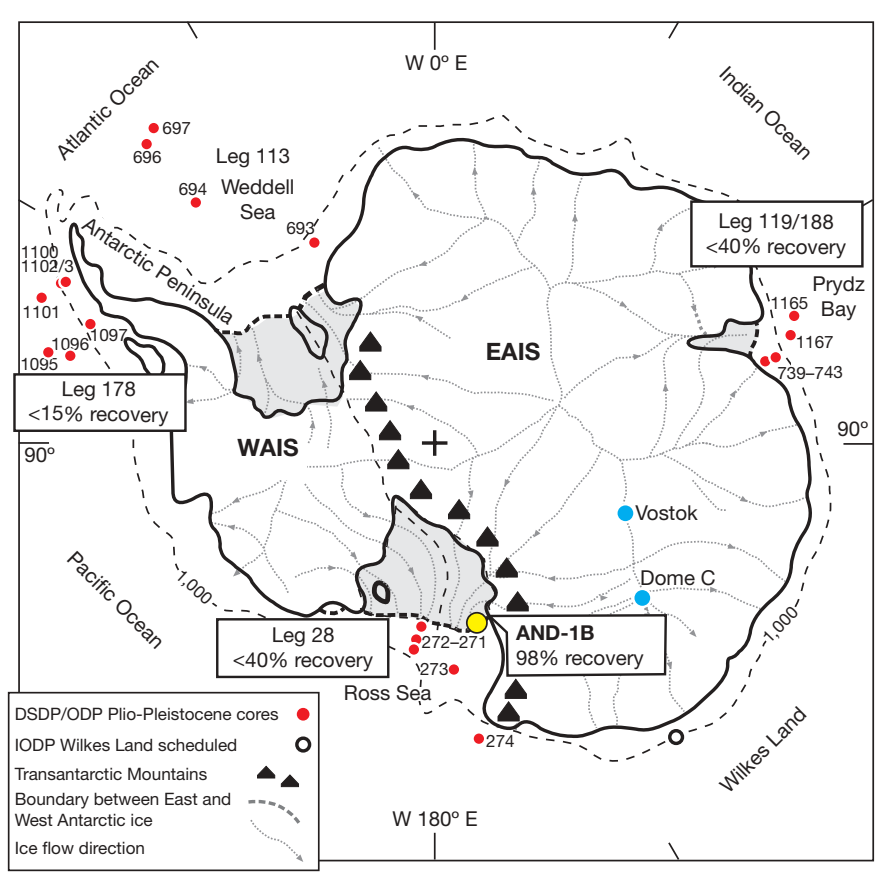

Figure 1 | Location of the ANDRILL McMurdo Ice Shelf Project AND-1B drill site in the northwestern corner of the Ross ice shelf. Also shown are the locations of previous Deep Sea Drilling Project (DSDP), Integrated Ocean Drilling Program (IODP) and Ocean Drilling Program (ODP) cores, PlioPleistocene cores, percentage recovery (from shelf sites) and geographic features including ice-sheet configuration and flow lines. (Supplementary Figs 1 and 2 show more detail of the glaciologic and geologic setting). The dashed contour indicates a depth of $1,000 \mathrm{~m}$ below sea-level.

WAIS and the marine margins of the East Antarctic ice sheet (EAIS) during the warmest early Pliocene interglacials.

Thirty-eight glacimarine cycles, each bounded by glacial surfaces of erosion (GSEs), occur in the upper $600 \mathrm{~m}$ of the core, and record oscillations in the extent of an ice sheet in Ross embayment during the past $5 \mathrm{Myr}$ (Fig. 2) ${ }^{20}$. The drilled strata accumulated in the rift axis of the Victoria Land basin, $\sim 100 \mathrm{~km}$ seaward of the coast. Accommodation space for the preservation of the sediments, and their protection from subsequent glacial erosion, was provided by high rates of tectonic subsidence due to a unique combination of regional rift extension and flexure of the crust by local volcanic islands (Supplementary Information).

Figures 3 and 4 summarize our interpretations of individual sedimentary cycles in terms of the vertical occurrences of lithofacies, that is, sediments representing specific environments of deposition. These range from marine-diatom-rich deposits and mudstones deposited during interglacials to ice-proximal diamictites, conglomerates and sandstones representing glacial periods. During glacial periods, the ice sheet had a laterally extensive marine terminus extending well beyond the drill site, out into the Ross Sea. During interglacials, the drill site was either covered by an ice shelf or, when the ice sheet retreated, lay in open water. The sedimentary characteristics of the cycles and the approach used for their interpretation are given in more detail elsewhere $^{21}$ (Methods). We note here that changes in lithofacies through time primarily reflect the proximity of the ice-sheet grounding zone and the thermal characteristics of the depositing ice (Fig. 2 and Supplementary Information). Such inferences are consistent with depositional models from a variety of different glacimarine regimes $^{22,23}$, and permit the identification of 38 oscillations in the extent of the ice sheet's grounding line.

The composition of till (ice-contact diamictites), which overlie GSEs and represent sediments transported at the base of a grounded ice sheet, show that the ice originated from large outlet glaciers in the Transantarctic Mountains (TAM), especially the Mulock and Skelton glaciers south of Minna Bluff ${ }^{21}$. A new continental Antarctic ice-sheet model $^{7}$ run for the past $5 \mathrm{Myr}$ supports geological interpretations that the provenance of grounded ice at the AND-1B site is always from nearby southern-TAM outlet glaciers during glacial advances (Fig. 2).

Notably, the model finds that local ice variations at the AND-1B site are indicative of the overall West Antarctic glacial state, because both are controlled by variations in ocean-induced melt. When open-water marine sediments occur in the AND-1B core, the model shows not only deglaciation in the western Ross embayment, but also the collapse of the entire WAIS (Fig. 2). Pliocene-Pleistocene variations in ice volume are dominated by large WAIS advances and retreats, while the high-altitude regions of the EAIS remain relatively stable. This is because air temperatures never become warm enough to cause significant surface melting on the EAIS ${ }^{24}$, whereas variations in ocean-induced melt and sea level affect the marine-based WAIS much more than the EAIS. Thus, the sedimentary cycles in the AND$1 \mathrm{~B}$ core both track local variations of the coastal margin of the EAIS (for example TAM outlet glaciers) and provide physical evidence for major changes in the mass balance of the WAIS (Supplementary Information).

Figure 2 illustrates the stratigraphic position of 26 chronological datums that are used to constrain the age and duration of the 38 sedimentary cycles and identify the time missing at cycle-bounding erosion surfaces, that is, unconformities (Supplementary Table 1). The chronology is developed from ${ }^{40} \mathrm{Ar} /{ }^{39} \mathrm{Ar}$ ages of volcanic deposits and a quantitative diatom biostratigraphy used to constrain the correlation between the magnetic polarity stratigraphy and the geomagnetic polarity timescale ${ }^{21}$. The approach used, and associated uncertainties, are outlined in Methods. About $36 \%$ of the last $5 \mathrm{Myr}$ is represented as rock in the AND-1B core; the rest is lost at unconformities resulting from erosion through long-term tectonic influences and shorter-term volcanic and glacial processes. Chronostratigraphic constraints enable identification of two types of unconformities: (1) those where the time missing is longer than a Milankovitch cycle, interpreted as major erosion due to tectonic influences and/or a major phase of glacial advance; and (2) those of suborbital duration reflecting lesser glacial erosion associated with a single glacial advance truncating only part of the previous cycle. The chronology also allows the duration of relatively continuous stratigraphic packages comprising more than one cycle to be estimated with sufficient precision for the recognition of orbital periods $^{25}$ (Methods).

One such interval is illustrated in detail in Fig. 3 and comprises six early-Pliocene glacial cycles (cycles 38-33), spanning $265 \mathrm{kyr}$. In this case, the identification of three palaeomagnetic reversal boundaries allows one-to-one matching of the WAIS grounding-line oscillations recorded in the AND-1B core to individual 40-kyr ice-volume cycles in the deep-sea benthic $\delta^{18} \mathrm{O}$ stack $^{26}$ and modelled ice-volume cycles between 4.896 and $4.631 \mathrm{Myr}$ ago. Figure 4 illustrates an interval in which the chronology constrains 16 successive early- to mid-Pliocene (3.60-2.87 Myr ago) cycles (32a-d to 20), spanning $700 \mathrm{kyr}$. In this case, the cyclostratigraphic interpretation and the distribution of time within the AND-1B core are not so straightforward, primarily because a $\sim 60$-m-thick interval of marine diatomite, spanning $\sim 200 \mathrm{kyr}$, occurs between 438 and 376 m.b.s.f. We use the distribution of $>2$-mm-diameter iceberg-rafted debris (IBRD) through the continuous, thick diatomite unit as an index for ice-rafting intensity and glacial variability. The IBRD record identifies four or five main orbital cycles (32a-d) reflecting glacial fluctuations during an extended period of biopelagic deposition in the Ross embayment, when the ice sheet remained landward of the drill site (Fig. 2). The composition of the IBRD reflects oscillations of local outlet glaciers, which remained near the coast with no significant expansion into the Ross Sea $^{21}$.

If the four or five IBRD cycles in the diatomite and the eleven overlying unconformity-bounded cycles are distributed evenly over this time interval, the resulting duration is $\sim 40 \mathrm{kyr}$ per cycle (Fig. 4 ). 
The short-duration normal-polarity interval between the Mammoth and Kaena subchrons is not represented in the AND-1B core and could be missing at any of the GSEs between the bases of cycles 28-22. However, if cycles 28-22 are distributed evenly across the amalgamated reversed-polarity subchrons between 3.30 and 3.03 Myr ago, then a one-to-one match with $\sim 40$-kyr $\delta^{18} \mathrm{O}$ cycles results and suggests that an intervening normal-polarity interval is most likely missing at the basal GSE of cycle 26.

The 60-m-thick diatomite unit lacks a sea-ice-associated diatom flora $^{27}$, and sedimentological evidence implies that warmer-than-present

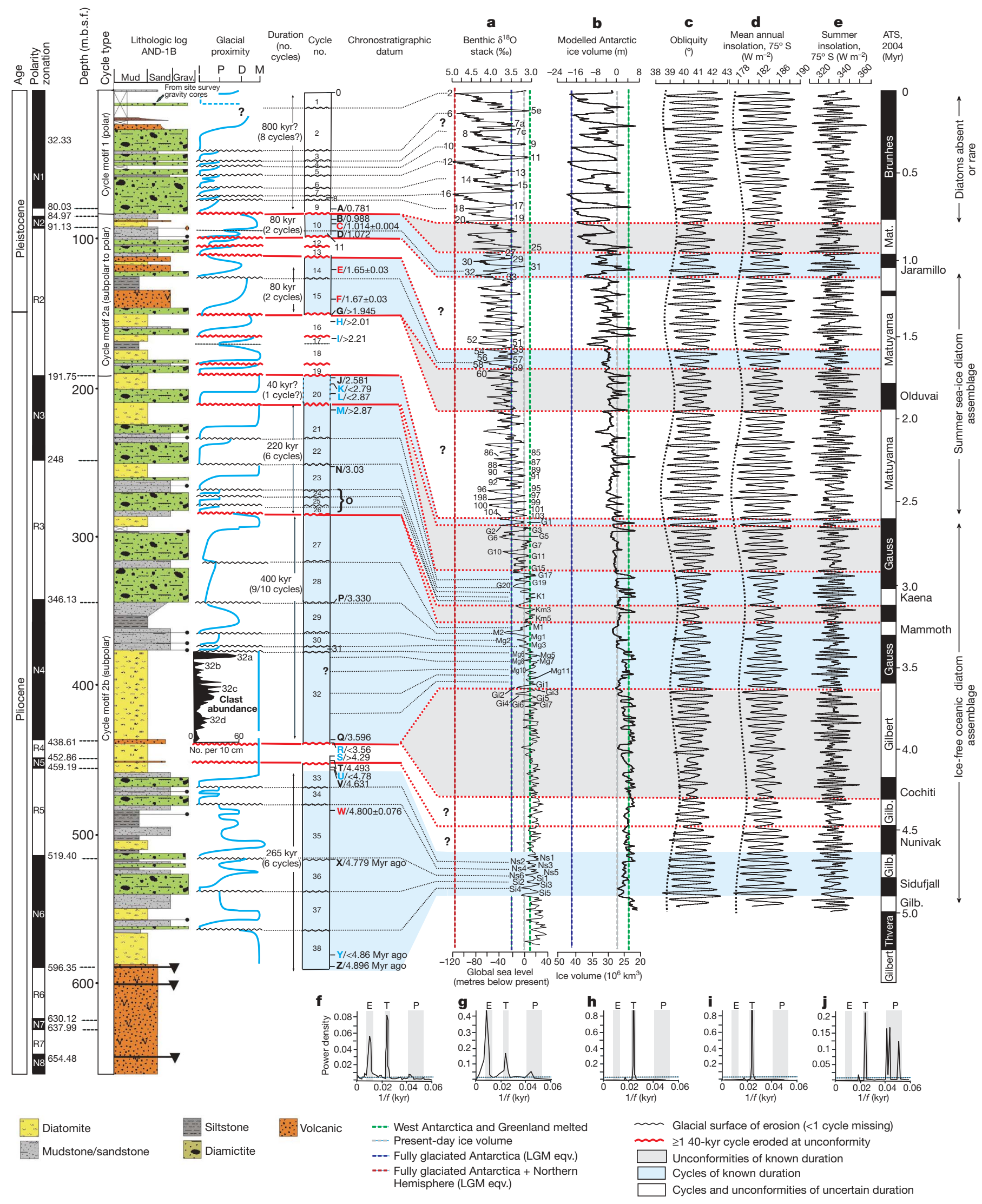




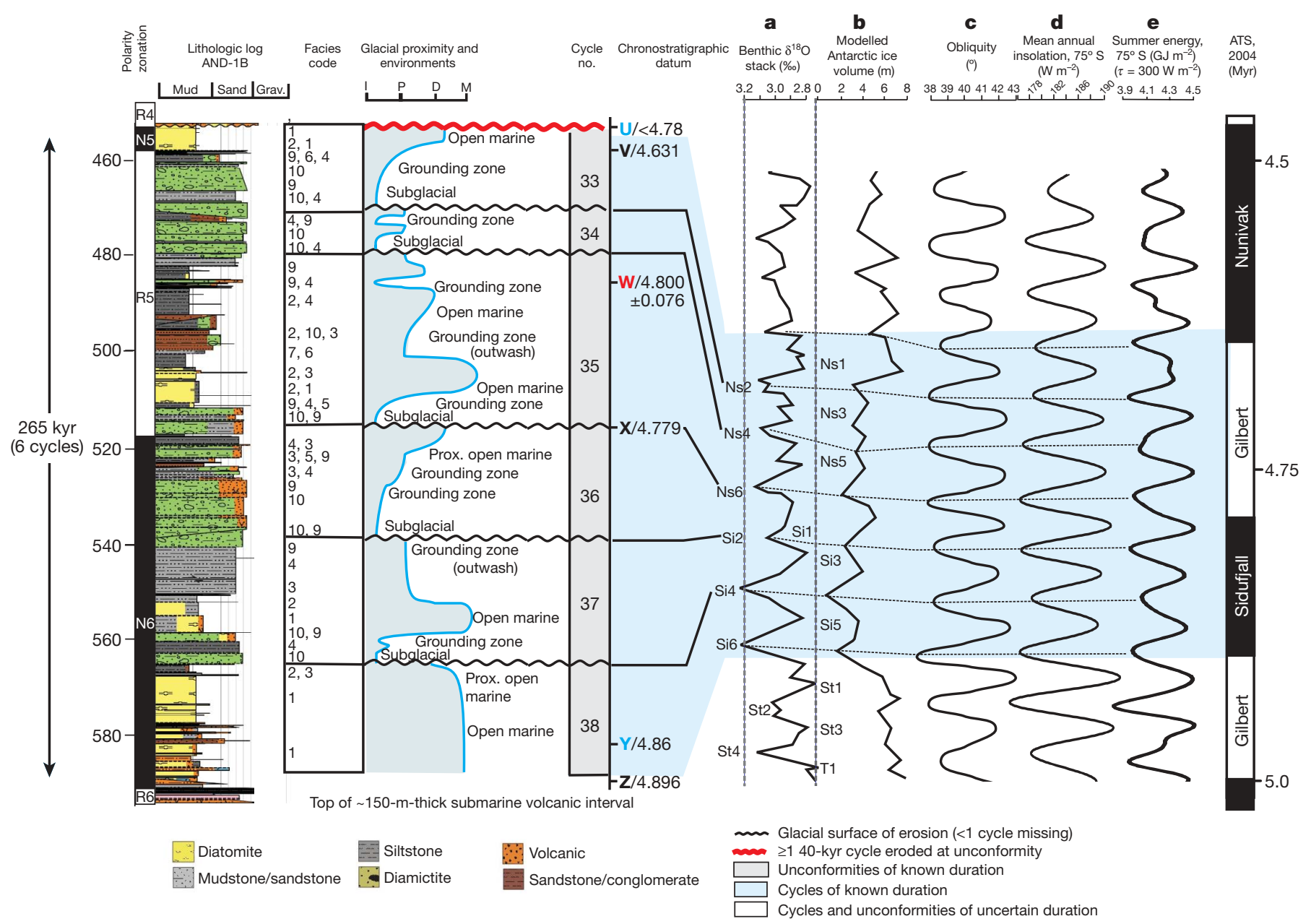

Figure 3 | Detailed analysis of early-Pliocene sedimentary cycles in the AND-1B core showing lithofacies interpretations of glacimarine

environments. The glacial proximity curve tracks the relative position of the grounding line through ice-contact (I), ice-proximal (P), ice-distal (D) and marine $(\mathrm{M})$ environments and provides a proxy for ice-sheet extent. Cycle duration is constrained by chronostratigraphic datums coded $\mathrm{A}-\mathrm{Z}$. The chronostratigraphy allows a one-to-one correlation of the cycles with

oceanic and atmospheric conditions existed between $\sim 3.6$ and $3.4 \mathrm{Myr}$ ago. Foraminiferal $\delta^{18} \mathrm{O}$ values during this time are up to $0.4 \%$ lower than during the Holocene epoch, with amplitudes of 0.15 to $0.35 \%$ equivalent to eustatic sea-level fluctuations (including Northern Hemisphere ice; see Methods) of $+10-30 \mathrm{~m}$. Modelled Antarctic ice volume reduces to $20 \times 10^{6} \mathrm{~km}^{3}$, or $+7 \mathrm{~m}$ in equivalent sea level (Fig. 2), and involves the complete deglaciation of WAIS together with a loss of up to $+3 \mathrm{~m}$ in equivalent sea level $(5 \%)$ from the marine margins of the EAIS ${ }^{7}$. If complete deglaciation of Greenland $(+5 \mathrm{~m})$ also occurred during this time, then the Antarctic ice-sheet history from isotopes, proximal data and numerical models is in good agreement with the early-Pliocene eustatic sea-level fluctuation amplitudes of $+10-30 \mathrm{~m}$ obliquity-paced time series of the benthic $\delta^{18} \mathrm{O} \operatorname{record}^{26}(\mathbf{a})$, modelled Antarctic ice volume ${ }^{7}$ (expressed in metres of equivalent sea level, b), obliquity (c), mean annual insolation at $75^{\circ} \mathrm{S}(\mathrm{d})$, and summer energy at $75^{\circ} \mathrm{S}$ for inferred melt threshold $(\tau)$ of $300 \mathrm{~W} \mathrm{~m}^{-2}$ (e; see Supplementary Information for further explanation of summer energy). Dashed vertical lines represent present-day ice volume/sea level. (See Methods and Supplementary Table 2 for explanation of facies codes.)

reconstructed from far-field sites such as the uplifted shallow-marine Wanganui basin (New Zealand) ${ }^{18}$.

The WAIS grounding line re-advanced across the western Ross Sea following deposition of the thick diatomite interval, as shown by the occurrence of progressively more ice-proximal facies in the core between sedimentary cycles 31 and 29 (Fig. 4). The interval is correlated with a $0.7 \%$ increase in $\delta^{18} \mathrm{O}$ between marine isotope stages Mg5 and $\mathrm{M} 2$, and a corresponding increase in modelled Antarctic ice volume equivalent to a eustatic fall from $7 \mathrm{~m}$ above present-day sea level to $1 \mathrm{~m}$ below $^{7}$. The M2 glacial appears to terminate early-Pliocene warm conditions in the Ross embayment. Our glacial proximity curve shows that WAIS expansion across the drill site occurred during the early
Figure 2 | Stratigraphic and chronologic summary of the upper $600 \mathrm{~m}$ of the AND-1B core showing 38 sedimentary cycles of ice-sheet advance, retreat and re-advance during the last $\mathbf{5}$ Myr. Lithologies (rock types) are plotted against depth. The glacial proximity curve tracks the relative position of the grounding line through ice-contact (I), ice-proximal (P), ice-distal (D) and marine $(\mathrm{M})$ environments and provides a proxy for ice-sheet extent. Cycle duration is constrained by chronostratigraphic datums coded $\mathrm{A}-\mathrm{Z}$ (Supplementary Table 1) and is explained in more detail in Methods. The chronostratigraphy allows correlation of some cycles (blue shading) with time series of the stacked benthic $\delta^{18} \mathrm{O}$ record ${ }^{26}\left(\delta^{18} \mathrm{O}=\left({ }^{18} \mathrm{O} /{ }^{16} \mathrm{O}\right)_{\text {sample }} /\right.$ $\left({ }^{18} \mathrm{O} /{ }^{16} \mathrm{O}\right)_{\text {SMOW }}-1$; SMOW, standard mean ocean water; $\left.\mathbf{a}\right)$, model-output Antarctic ice volume ${ }^{7}$ (expressed in metres of equivalent sea level, b), obliquity (c), mean annual insolation at $75^{\circ} \mathrm{S}$ (d) and summer insolation intensity at $75^{\circ} \mathrm{S}(\mathbf{e})$. Spectral estimates show that the majority of the variance is at $\sim 40$-kyr frequency for the $\delta^{18} \mathrm{O}$ record (f), obliquity (h) and mean annual insolation (i). Summer insolation at $75^{\circ} \mathrm{S}$ has equal power in the obliquity and precession bands (j). The relative increase in 100-kyr power in model-output Antarctic ice volume (g) reflects the increased influence of large Northern Hemisphere ice sheets on ocean temperature and glacioeustatic fluctuations in the late Pleistocene. In $\mathbf{f}-\mathbf{j}$ : E, eccentricity or $\sim 100$-kyr cycle of unknown origin; $\mathrm{T}$, tilt (obliquity); $\mathrm{P}$, precession; $f$, frequency; vertical axes, power as an arbitrary scale of relative spectral power. m.b.s.f., metres below sea floor; LGM, Last Glacial Maximum. Thin diamictites $(<3 \mathrm{~m})$ are represented by a horizontal line with dot at end. 


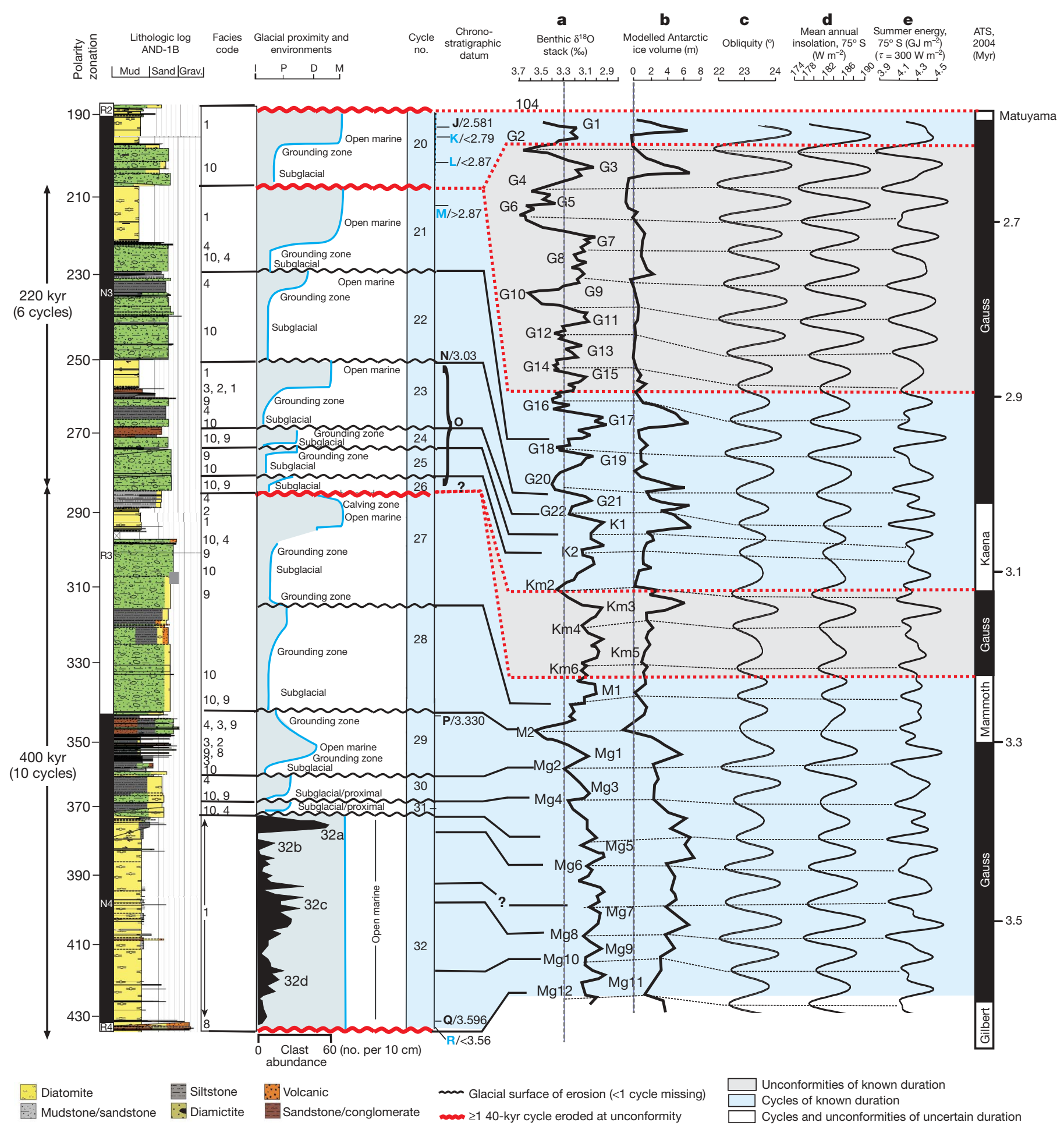

Figure 4 | Detailed analysis of late early-Pliocene sedimentary cycles in the AND-1B core showing lithofacies interpretations of glacimarine environments. Glacial proximity curve tracks the relative position of the grounding line through ice-contact (I), ice-proximal (P), ice-distal (D) and marine $(\mathrm{M})$ environments and provides a proxy for ice-sheet extent. Cycle duration is constrained by chronostratigraphic datums coded $\mathrm{A}-\mathrm{Z}$. The

Pliocene when Holocene $\delta^{18} \mathrm{O}$ values and present-day Antarctic ice volumes $\left(27 \times 10^{6} \mathrm{~km}^{3}\right)$ were exceeded. An up-core transition between 350 and 150 m.b.s.f. is evident, marked by successively fewer submarine outwash deposits and thinner grounding-zone facies successions representing cooling of the ice sheet implied by progressively lower volumes of melt water (Supplementary Information and ref. 21). This culminates with a major cooling step that occurs across the chronostratigraphy allows recognition of 15 cycles, within a $\sim 600-\mathrm{kyr}$ period, that are correlated with obliquity-paced time series of the benthic $\delta^{18} \mathrm{O}$ record $^{26}(\mathbf{a})$, modelled Antarctic ice volume ${ }^{7}(\mathbf{b})$, obliquity (c), mean annual insolation at $75^{\circ} \mathrm{S}(\mathrm{d})$ and summer energy at $75^{\circ} \mathrm{S}$ for $\tau=300 \mathrm{~W} \mathrm{~m}^{-2}$ (e). Dashed vertical lines represent present-day ice volume/sea level.

Gauss-Matuyama polarity transition (2.6 Myr ago) associated with significant erosion and loss of the late-Pliocene stratigraphic record (Fig. 2). This step is taken to represent a major expansion of the ice sheet.

The $\sim 40$-kyr-year variability in the size of the WAIS suggests differences from Milankovitch's hypothesis that summer half-year insolation intensity, with its sensitivity to precession (Fig. 2e), should control the growth and decay of ice sheets. Historically, the lack of 
precession in the geological record has been attributed to the importance of annual insolation that is controlled by obliquity, with more influence on polar temperatures than seasonal insolation modulated by precession (see, for example, ref. 28). Figure 2 highlights the relationship between obliquity (Fig. 2c), mean annual insolation (Fig. 2d) and the AND-1B cycles for the Pliocene, and Figs 3 and 4 show details for the early Pliocene. Given the sensitivity of WAIS mass balance to ocean temperature ${ }^{7}$, we suggest that $40-\mathrm{kyr}$ orbital cycles may regulate southward export and upwelling of Circumpolar Deep Water with consequences for melt rates at grounding lines of Antarctic ice sheets. Several recent studies have linked changes in Atlantic meridional overturning ${ }^{29}$ and Antarctic circumpolar ocean circulation $^{30}$ to obliquity forcing. An interglacial mechanism has been proposed whereby the southward expansion of westerly winds and associated northward Ekman transport is compensated for by enhanced upwelling of warmer, $\mathrm{CO}_{2}$-rich Circumpolar Deep Water ${ }^{30}$, which also promotes atmospheric warming. Such a positive feedback is supported by the strong correlation between temperature and $\mathrm{CO}_{2}$ in Antarctic ice-core records and may accelerate sea-ice loss with attendant changes in albedo, further increasing oceanic and atmospheric warming.

The low abundance of sea-ice-associated diatoms $(<5 \%)$ in the early-Pliocene diatomite intervals of the AND-1B cycles suggests that sea surface and air temperatures may have been above freezing for a significant part of the austral summer. On long timescales, insolation integrated over the length of summer (summer energy) has been shown in models to control the surface melting of ice sheets at the obliquity period ${ }^{8}$ (Supplementary Information), provided that the ablating margin is at high latitude and that the surface temperature remains above $0{ }^{\circ} \mathrm{C}$ for a significant part of the season ${ }^{31}$. Although the latter condition is not currently met by the Antarctic ice sheet, its surface melt threshold may have been exceeded during the early Pliocene and may be exceeded again in the next 100 years. Given the geological evidence from the AND-1B core, we suggest that the mass balance of the early-Pliocene Antarctic ice sheet, although primarily controlled by ocean-induced melting ${ }^{7}$, may also have been influenced by surface ablation (Figs 3 and 4). A recent model of the early-Pliocene terrestrial EAIS implies sensitivity to surface temperature on its low-elevation margins at an atmospheric $\mathrm{CO}_{2}$ level of 400 p.p.m. (ref. 32). Furthermore, documented in-phase insolationlinked warming during an early-Pleistocene interglacial ${ }^{33}$ suggests that significant melt may occur during precession-amplified obliquity cycles (Supplementary Information). More well-dated sediment cores, and future experiments using ice-sheet models (see, for example, ref. 7), are planned to assess more fully the different influences of orbital forcing on surface ablation versus oceaninduced melt at elevated atmospheric $\mathrm{CO}_{2}$ levels.

The unconformity-bounded glacimarine cycles in the AND-1B core provide ice-proximal evidence for $\sim 40$-kyr oscillations in Pliocene WAIS and in some of the EAIS outlet glaciers draining into the Ross embayment south of the drill site, a type of behaviour similar to that of the unstable Northern Hemisphere ice sheets of the past $\sim 3 \mathrm{Myr}$.

\section{METHODS SUMMARY}

The 98\%-complete AND-1B drill core was recovered from $\sim 850 \mathrm{~m}$ of water, from an 85-m-thick portion of the Ross ice shelf, west of Ross Island (Fig. 1 and Supplementary Fig. 1). Drilling used a custom-built riser system embedded into the sea floor, enabling continuous wireline diamond-bit coring to a depth of 1284.87 m.b.s.f. The core was initially processed at the drill site and transported to McMurdo Station on Ross Island where it was split, logged, sampled and analysed. An initial science report provides a summary of drilling, curation and science methods and the initial results that underpin many of the interpretations in this paper $^{21}$.

The 38 glacimarine sedimentary cycles are recognized on the basis of the repetitive vertical occurrence of characteristic facies within the AND-1B core. These facies and their interpretations are summarized in Supplementary Table 2, and shown for a single cycle in Supplementary Fig. 3. The age model for the AND-1B core was developed from quantitative diatom biostratigraphic and ${ }^{40} \mathrm{Ar} /{ }^{39} \mathrm{Ar}$ radiometric ages to constrain the correlation between the magnetic polarity stratigraphy and the geomagnetic polarity timescale. Chronostratigraphic data are summarized in Supplementary Table 1. The biostratigraphic and radiometric datums alone are not used for absolute age control or correlation of cycles with the $\delta^{18} \mathrm{O}$ record, because their numeric ages have uncertainties of up to $\pm 50 \mathrm{kyr}$. However, their precision is sufficient to match polarity zones, identified in the core, with the geomagnetic polarity timescale. These higher-precision $( \pm 5 \mathrm{kyr})$ geomagnetic polarity transitions provide the 'time spikes' for cycle correlation and estimation of cycle duration. For example, the six early-Pliocene glacial cycles between 4.896 and 4.493 Myr ago (Fig. 3) are correlated with C3n.3n/C3n.2r (mid Gilbert, 4.896-4.631 Myr ago) spanning $265 \mathrm{kyr}$ (Fig. 3). Linear interpolation between the dated polarity transitions implies average durations of $39 \mathrm{kyr}$ and 48 kyr per cycle for the lower three (polarity zone N6) and upper three (polarity zone R5) cycles, respectively.

Full Methods and any associated references are available in the online version of the paper at www.nature.com/nature.

\section{Received 25 July 2008; accepted 11 February 2009}

1. Hays, J. D., Imbrie, J. \& Shackleton, N. J. Variations in the Earth's orbit; pacemaker of the ice ages. Science 194, 1121-1132 (1976).

2. Raymo, M. E. \& Huybers, P. Unlocking the mysteries of the ice ages. Nature 415, 284-285 (2008)

3. Intergovernmental Panel on Climate Change in Climate Change 2007: The Physical Science Basis. Contribution of Working Group I to the Fourth Assessment Report of the Intergovernmental Panel on Climate Change (eds Solomon, S. et al.) 707-709 (Cambridge Univ. Press, 2007).

4. Kim, S. J. \& Crowley, T. J. Increased Pliocene North Atlantic Deep Water: cause or consequence of Pliocene warming. Paleoceanography 15, 451-455 (2000).

5. Van Der Burgh, J., Visscher, H., Dilcher, D. \& Kürschner, M. Paleoatmospheric signatures in Neogene fossil leaves. Science 260, 1788-1790 (1993).

6. Raymo, M. E., Grant, B., Horowitz, M. \& Rau, G. H. Mid-Pliocene warmth: stronger greenhouse and stronger conveyor. Mar. Micropaleontol. 27, 313-326 (1996).

7. Pollard, D. \& DeConto, R. M. Modelling West Antarctic ice sheet growth and collapse through the past five million years. Nature (this issue).

8. Huybers, P. Early Pleistocene glacial cycles and the integrated summer insolation forcing. Science 313, 508-511 (2006).

9. Shackleton, N. J. et al. Oxygen isotope calibration of the onset of ice-rafting and history of glaciation in the North Atlantic region. Nature 307, 620-623 (1984).

10. Hall, I. R., McCave, I. N., Shackleton, N. J., Weedon, G. P. \& Harris, S. E. Intensified deep Pacific inflow and ventilation in Pleistocene glacial times. Nature 412, 809-812 (2001)

11. Crundwell, M., Scott, G., Naish, T. R. \& Carter, L. Glacial-interglacial oceanclimate variability spanning the Mid-Pleistocene transition in the temperate Southwest Pacific, ODP site 1123. Palaeogeogr. Palaeoclimatol. Palaeoecol. 260, 202-229 (2008)

12. Dwyer, G., Baker, P. \& Cronin, T. North Atlantic deepwater temperature change during late Pliocene and late Quaternary climatic cycles. Science 270, 1347-1350 (1995).

13. Ding, Z. L. et al. Stacked 2.6-Ma grain size record from the Chinese loess based on five sections and correlation with the deep-sea $\delta^{18} \mathrm{O}$ record. Paleoceanography 17 , 5-21 (2002).

14. Naish, T. R. Constraints on the amplitude of late Pliocene eustatic sea-level fluctuations: new evidence from the New Zealand shallow-marine sediment record. Geology 25, 1139-1142 (2007).

15. Raymo, M. E., Lisiecki, L. \& Nisancioglu, K. Plio-Pleistocene ice volume, Antarctic climate, and the global $\delta^{18} \mathrm{O}$ record. Science 313, 492-495 (2006).

16. Mercer, J. H. West Antarctic ice sheet and $\mathrm{CO}_{2}$ greenhouse effect: a threat of disaster. Nature 271, 321-325 (1978).

17. Dowsett, J. \& Cronin, T. M. High eustatic sea level during the middle Pliocene: evidence from the southeastern U.S. Atlantic Coastal Plain. Geology 18, 435-438 (1990).

18. Naish, T. R. \& Wilson, G. Constraints on the amplitude of Mid-Pliocene (3.6-2.4 $\mathrm{Ma}$ ) eustatic sea-level fluctuations from the New Zealand shallow-marine sediment record. Phil. Trans. R. Soc. A 367, 169-187 (2009).

19. Kennett, J. P. \& Hodell, D. A. Evidence for relative climatic stability of Antarctica during the Early Pliocene: A marine perspective. Geogr. Ann. 75A, 202-222 (1993)

20. Naish, T. R. et al. in Antarctica: A Keystone in a Changing World (eds Cooper, A. K. et al.) 71-82 (Proc. 10th Internat. Symp. Antarctic Earth Sci., National Academies Press, 2008)

21. Naish, T. R., Powell, R. D. \& Levy, R. H. (eds) Studies from the ANDRILL, McMurdo Ice Shelf Project, Antarctica - Initial Science Report on AND-1B (Terra Antartica Vol. 14, 2007).

22. Dunbar, G., Naish, T. R., Powell, R. D. \& Barrett, P. J. Constraining the amplitude of late Oligocene bathymetric changes in western Ross Sea during orbitally-induced oscillations in the East Antarctic Ice Sheet: (1) Implications for glacimarine sequence stratigraphic model. Palaeogeogr. Palaeoclimatol. Palaeoecol. 260, 50-65 (2008) 
23. Powell, R. D. \& Cooper, J. M. A sequence stratigraphic model for temperate, glaciated continental shelves. Spec. Publ. Geol. Soc. (Lond.) 203, 215-244 (2003)

24. Lewis, A. R. et al. Mid-Miocene cooling and the extinction of tundra in continental Antarctica. Proc. Natl Acad. Sci. USA 105, 10676-10689 (2008).

25. Naish, T. R., Carter, L., Wolff, E., Pollard, D. \& Powell, R. D. in Developments in Earth \& Environmental Sciences Vol. 8 (eds Florindo, F. \& Seigert M.) 465-529 (Elsevier, 2009).

26. Lisiecki, L. E. \& Raymo, M. E. A. Pliocene-Pleistocene stack of 57 globally distributed benthic $\delta^{18} \mathrm{O}$ records. Paleoceanography 20, doi:10.1029/ 2005PA001153 (2005).

27. McKay, R. et al. Retreat of the Ross Ice Shelf since the Last Glacial Maximum derived from sediment cores in deep basins surrounding Ross Island. Palaeogeogr. Palaeoclimatol. Palaeoecol. 260, 245-261 (2008).

28. Young, M. \& Bradley, R. in Milankovitch and Climate (eds Berger, A. et al.) 707-713 (Riedel, 1984)

29. Lisiecki, L. E., Raymo, M. E. \& Curry, W. B. Atlantic overturning responses to Late Pleistocene climate forcings. Nature 456, 85-88 (2008).

30. Toggweiler, J. R., Russell, J. L. \& Carson, S. R. Mid-latitude westerlies, atmospheric $\mathrm{CO}_{2}$, and climate change. Paleoceanography 21, doi:10.1029/2005PA001154 (2007).

31. Huybers, P. \& Tziperman, E. Integrated summer insolation forcing and 40,000year glacial cycles: the perspective from an ice-sheet/energy-balance model. Paleoceanography 23, doi:10.1029/2007PA001463 (2008).

32. Hill, D. J., Haywood, A. M., Hindmarsh, R. C. A. \& Valdes, P. J. in Deep Time Perspectives on Climate Change: Marrying the Signals from Computer Models and Biological Proxies (eds Williams, M. et al.) 517-538 (Micropalaeontol. Soc. Spec. Publ., Geological Society of London, 2007).

33. Scherer, R. P. et al. Antarctic records of precession paced, insolation-driven warming during the early Pleistocene Marine Isotope Stage 31. Geophys. Res. Lett. 35, doi:10.1029/2007gl032254 (2008).

Supplementary Information is linked to the online version of the paper at www.nature.com/nature.

Acknowledgements The ANDRILL project is a multinational collaboration between the Antarctic programmes of Germany, Italy, New Zealand and the United States. Antarctica New Zealand is the project operator and developed the drilling system in collaboration with A. Pyne. Antarctica New Zealand supported the drilling team at Scott Base; Raytheon Polar Services Corporation supported the science team at McMurdo Station and the Crary Science and Engineering Laboratory. The ANDRILL Science Management Office at the University of Nebraska-Lincoln provided science planning and operational support. The scientific studies are jointly supported by the US National Science Foundation, the New Zealand Foundation for Research Science and Technology and the Royal Society of New Zealand Marsden Fund, the Italian Antarctic Research Programme, the German Research Foundation and the Alfred Wegener Institute for Polar and Marine Research.

Author Contributions All authors contributed to acquisition, analysis and interpretation of data presented in this paper. T.N.: overall coordination of writing, sedimentology, cyclostratigraphic and climatic interpretations; R.P.: integration, glacial facies, glacial process and interpretations of ice-sheet history; R.L.: integration, biochronology and age-model construction; L.K.: core description and sedimentological interpretation; F.N.: core description and physical properties interpretation; M.P.: petrological interpretation; R.S.: integration, diatom biostratigraphic and environmental interpretations; F.T.: clast abundance, composition and provenance interpretations; G.W.: palaeomagnetic stratigraphy and age-model construction; T. Wilson: core description, structural and tectonic constraints; L.C.: sedimentology \& palaeo-oceanographic interpretations; R. McKay: sedimentology, glacial facies interpretations and ice-sheet history; J. Ross: ${ }^{40} \mathrm{~A} /{ }^{39} \mathrm{Ar}$ geochronology and age-model construction; D.W.: diatom biostratigraphy and environmental interpretations; P.B.: glacial process and interpretations of ice-sheet history; G.B.: glacimarine sequence stratigraphy and facies interpretations; R.C.: biochronology and age-model construction; E.C.: glacial facies, glacial process and interpretations of ice-sheet history; J.C.: biochronology and age-model construction; R.D.: ice-sheet-model data interpretation and integration; G.D.: core description, facies and sedimentological interpretation; N.D.: ${ }^{40} \mathrm{Ar} /{ }^{39} \mathrm{Ar}$ geochronology and petrological interpretation; F.F.: palaeomagnetic interpretations and age-model construction; C.G.: core description and physical properties interpretation; I.G.: geochronology and age-model construction; M.H.: biostratigraphy and environmental interpretation; D. Harwood: diatom biostratigraphy and biochronology; D. Hansaraj: regional seismic stratigraphic context; D. Helling: geochemical interpretation; S.H.: regional stratigraphic framework and tectonic constraints; L.H.: time-series analysis; P.H.: Milankovitch forcing and palaeoclimatic interpretations; G.K.: geochemical interpretation; P.K.: volcanic petrology and volcanological interpretation; A.L.: core description and structural analysis; P.M.: diatom biostratigraphy and environmental interpretations; D.M.: core description and physical properties interpretation; K.M.: core description; W.M.: ${ }^{40} \mathrm{Ar} /{ }^{39} \mathrm{Ar}$ geochronology and volcanological interpretation; C.M.: core description and structural analysis; R. Morin: borehole description and down-hole geophysics; C.O.: palaeomagnetic stratigraphy and age-model construction; T.P.: core and description and structural geology; D. Persico: calcareous nannofossil biostratigraphy; D. Pollard: ice-sheet-model data interpretation and integration; J. Reed: core description and visualization; C.R.: diatom biostratigraphy and environmental interpretation; I.R.: palynology and environmental interpretation; D.S.: core and borehole description and structural geology; L.S.: palaeomagnetic stratigraphy and age-model construction; C.S.: diatom biostratigraphy and environmental interpretation; P.S.: foram biostratigraphy and environmental interpretation; M.T.: macrofossil biostratigraphy and environmental interpretation; S.V.: subglacial geological interpretation; T. Wilch: core description and interpretation of volcaniclastic sediments; T. Williams: borehole description and down-hole geophysics.

Author Information Reprints and permissions information is available at www.nature.com/reprints. Correspondence and requests for materials should be addressed to T.N. (tim.naish@vuw.ac.nz). 


\section{METHODS}

Facies analysis of sedimentary cycles and the interpretation of glacial proximity. The individual glacimarine cycles are interpreted to represent ice advance-retreatre-advance of the grounding line of a laterally continuous ice sheet in Ross embayment, and (from bottom to top) include the following stratigraphic elements.

(1) Erosion and subglacial deposition by an advancing ice sheet producing a GSE that is sharp, planar to sub-horizontal and truncates underlying deposits. Syndepositional soft-sediment deformation structures, intraclasts, clastic dykes and shearing of lithologies occur above and below the GSE. Subglacial features are also indicated by clast orientation and striation within tills.

(2) An interval of grounding-zone deposition comprising conglomerates and poorly sorted stratified sandstones together with stratified diamictite represent a range of basal meltwater conditions observed from subpolar to polar environments ${ }^{34}$, and are associated with glacimarine processes including subglacial meltwater outwash, proglacial debris-flow deposition, and iceberg rainout. These pass upwards into finer-grained terrigenous sediments representing more distal deposition from turbid plumes and grounding-line fans as the grounding line continues to retreat ${ }^{35,36}$. In some cases, ice-shelf environments are indicated by non-fossiliferous, unbioturbated intervals of interstratified sands and silts occurring stratigraphically between ice-proximal and open-marine facies ${ }^{37}$.

(3) Open-marine hemipelagic and pelagic sedimentation with and without iceberg influence. The distal deposits with least glacial influence are diatomites representing biogenic sediment accumulation in an ice-free, highly productive ocean setting.

(4) A proglacial facies succession of progressively more proximal groundingzone deposits (as in (2)), represents ice-sheet re-advance and eventual glacial overriding at the drill site. This may or may not be preserved below the GSE, depending on the degree of erosion on the GSE.

Several facies commonly associated with proximal glacimarine deposition are noted in AND-1B (Supplementary Table 2), including mudstone with dispersed clasts, conglomerates, sorted sandstone (with a TAM provenance), conglomerates and rhythmically interlaminated couplets of claystone with either siltstone or very fine-grained sandstone (see, for example, Supplementary Fig. 3). The changing abundance of these facies throughout the core, and comparison with modern-day analogues, provides insight into the past extent of subglacial meltwater processes following the concepts established for the Cape Roberts Project core ${ }^{38}$. For example, the rhythmically interlaminated claystone with silt/sandstone facies in AND-1B are consistent with previously described cyclopsam and cyclopel facies from modern temperate to subpolar glacimarine environments in Alaska and the Greenland margin, where they are deposited in quiet-water basins by suspension settling from meltwater plumes ${ }^{35,36}$. These sediments are unknown in modernday Antarctic glacimarine settings, yet are common in temperate to subpolar settings $s^{39}$.

Chronostratigraphic constraints. A preliminary age model for the upper $600 \mathrm{~m}$ of the drill core constructed from diatom biostratigraphy, and radiometric ages on volcanic material, allows a unique correlation of $\sim 36 \%$ of the magnetic polarity stratigraphy with the geomagnetic polarity timescale. Since publication of this age model $^{21}$, the chronology has been improved by further diatom biostratigraphic analysis of the diatomite interval between 460 and 383 m.b.s.f. We now identify a significant hiatus of $\sim 800 \mathrm{kyr}$ at the base of a volcaniclastic gravity-flow deposit at $\sim 440.12$ m.b.s.f. Additionally, a new ${ }^{40} \mathrm{Ar} /{ }^{39} \mathrm{Ar}$ potassium feldspar age of $4.800 \pm 0.076 \mathrm{Myr}$ on a primary volcanic deposit at $481.80 \mathrm{~m}$.b.s.f. (Supplementary Information) confirms the correlation of our magnetic polarity stratigraphy with the geomagnetic polarity timescale for this early-Pliocene interval of the core. All chronostratigraphic datums used to constrain estimates of cycle duration, and correlations with proxy climate and climate-forcing time series in Fig. 2 and Supplementary Fig. 4 for the upper $600 \mathrm{~m}$ of the AND-1B core, are summarized in Supplementary Table 1.

Early-Pliocene chronostratigraphy between 400 and 600 m.b.s.f. Biostratigraphic event ages include the maximum and minimum ages identified in the CONOP constrained Southern Ocean diatom biochronologic calibration of ref. 40. The ages for new events described below are determined from recent model runs $^{41}$. The first occurrence of Rhizosolenia sp. D is observed at 440.12 m.b.s.f. The maximum age of this event is well constrained in the latest versions of the CONOP models (which incorporate AND-1B data). Rhizosolenia sp. D has been documented in at least seven sections from around the Antarctic ${ }^{40}$. The occurrence of this diatom event, therefore, requires the age of the core at and above 440.12 m.b.s.f. to be $<3.58 \mathrm{Myr}$. The palaeomagnetic zone in this portion of the core (440.12-346.13 m.b.s.f.) is normal and correlates C2An.3n (base of the Gauss chron, 3.596-3.300 Myr ago). The absence of Fragilariopsis interfrigidaria and Fragilariopsis barronii between 450 and 440.12 m.b.s.f. implies an age-range equivalent depth of $4.72-4.29$ m.b.s.f. for this interval and constrains the minimum duration of the unconformity below 440.12 m.b.s.f. to $\sim 800 \mathrm{kyr}$. The first occurrence of Thalassiosira striata is observed at 456.00 m.b.s.f., constraining the maximum age of the core at this level to $4.78 \mathrm{Myr}$ and identifying the short normal-polarity interval between 459.19 and 452.86 m.b.s.f. as the Nunivak subchron (C3n.2n, 4.631-4.493 Myr ago). The radiometric age of 4.8 $\pm 0.076 \mathrm{Myr}$ on the pumice-rich layer at 481.8 m.b.s.f. constrains the superjacent $\mathrm{N}-\mathrm{R}$ transition at 519.4 m.b.s.f. to the top of the Sidufjall subchron (4.799 Myr ago). The first occurrence of the marine diatom Thalassiosira complicata at 583.64 m.b.s.f. is $4.86 \mathrm{Myr}$ ago and constrains correlation of the R-N transition at 596.35 m.b.s.f. with the base of the Sidufjall subchron (4.896 Myr ago).

Calibration of the benthic foraminiferal $\delta^{18} \mathrm{O}$ curve to sea level. The stacked benthic foraminiferal $\delta^{18} \mathrm{O}$ record for the last $5 \mathrm{Myr}$ (ref. 25) was converted to a sea-level curve by scaling with a calibration of $0.011 \% \mathrm{~m}^{-1}$, which is consistent with ice-volume $\delta^{18} \mathrm{O}$ calibrations derived from a number of sources: uplifted Late Quaternary remnant shorelines ${ }^{42}$, equatorial planktonic foraminiferal isotope records with minimal temperature influence ${ }^{43}$ and back-stripped estimates of eustatic sea level from continental margin sequences ${ }^{14,44}$. The calibration removes a consistent $20 \%$ temperature contribution from the total amplitude of glacial-interglacial isotopic variation. For example, the LGM-to-Holocene shift in the stacked isotope curve of $1.7 \%$, when calibrated to the corresponding sea-level shift estimated from Huon Peninsula palaeoshoreline sequence, is 1.2$1.3 \%$ or $0.011 \% 0 \mathrm{~m}^{-1}$. The difference is due to glacial-interglacial deep-ocean temperature changes of $2{ }^{\circ} \mathrm{C}$ or $0.3-0.4 \%$.

34. Dowdeswell, J. A., Elverhøi, A. \& Spielhagen, R. Glacimarine sedimentary processes and facies on the Polar North Atlantic margins. Quat. Sci. Rev. 17, 243-272 (1998).

35. Ó Cofaigh, C., \&. Dowdeswell, J. A. Laminated sediments in glacimarine environments: diagnostic criteria for their interpretation. Quat. Sci. Rev. 20, 1411-1436 (2001).

36. Cowan, E. A., Seramur, K. C., Cai, J. \& Powell, R. D. Cyclic sedimentation produced by fluctuations in meltwater discharge, tides and marine productivity in an Alaskan fjord. Sedimentology 46, 1109-1126 (1999).

37. Domack, E. W., Jacobson, E. A., Shipp, S. \& Anderson, J. B. Late PleistoceneHolocene retreat of the West Antarctic ice-sheet system in the Ross Sea, Part 2: Sedimentologic and stratigraphic signature. Geol. Soc. Am. Bull. 111, 1517-1536 (1999).

38. Powell, R. D. et al. Facies analysis and depositional environments in CRP-3: implications for Oligocene glacial history. Terra Antartica 8, 207-217 (2001).

39. Powell, R. D. \& Domack, E. W. in Modern and Past Glacial Environments (ed. Menzies, J.) Ch. 12, 361-389 (Butterworth-Heinemann, 2002).

40. Cody, R., Levy, R., Harwood, D. \& Sadler, P. Thinking outside the zone: highresolution quantitative biochronology for the Antarctic Neogene. Palaeogeogr. Palaeoclimatol. Palaeoecol. 260, 92-121 (2008).

41. Cody, R, et al. Quantitative biostratigraphic modelling of the AND-1B drillcore. Glob. Planet. Change (submitted).

42. Chappell, J. et al. Reconciliation of Late Quaternary sea levels derived from coral terraces at Huon Peninsula with deep sea oxygen isotope records. Earth Planet. Sci. Lett. 141, 227-236 (1996).

43. Tiedemann, R., Sarnthein, M. \& Shackleton, N. J. Astronomical timescale for the Pliocene Atlantic $\delta^{18} \mathrm{O}$ and dust flux records of Ocean Drilling Program Site 659. Paleoceanography 9, 619-638 (1994).

44. Miller, K. G. et al. The Phanerozoic record of global sea-level change. Science 310, 1293-1298 (2005) 


\section{SUPPLEMENTARY INFORMATION}

\section{Supplementary Figure(s) and Legend(s)}
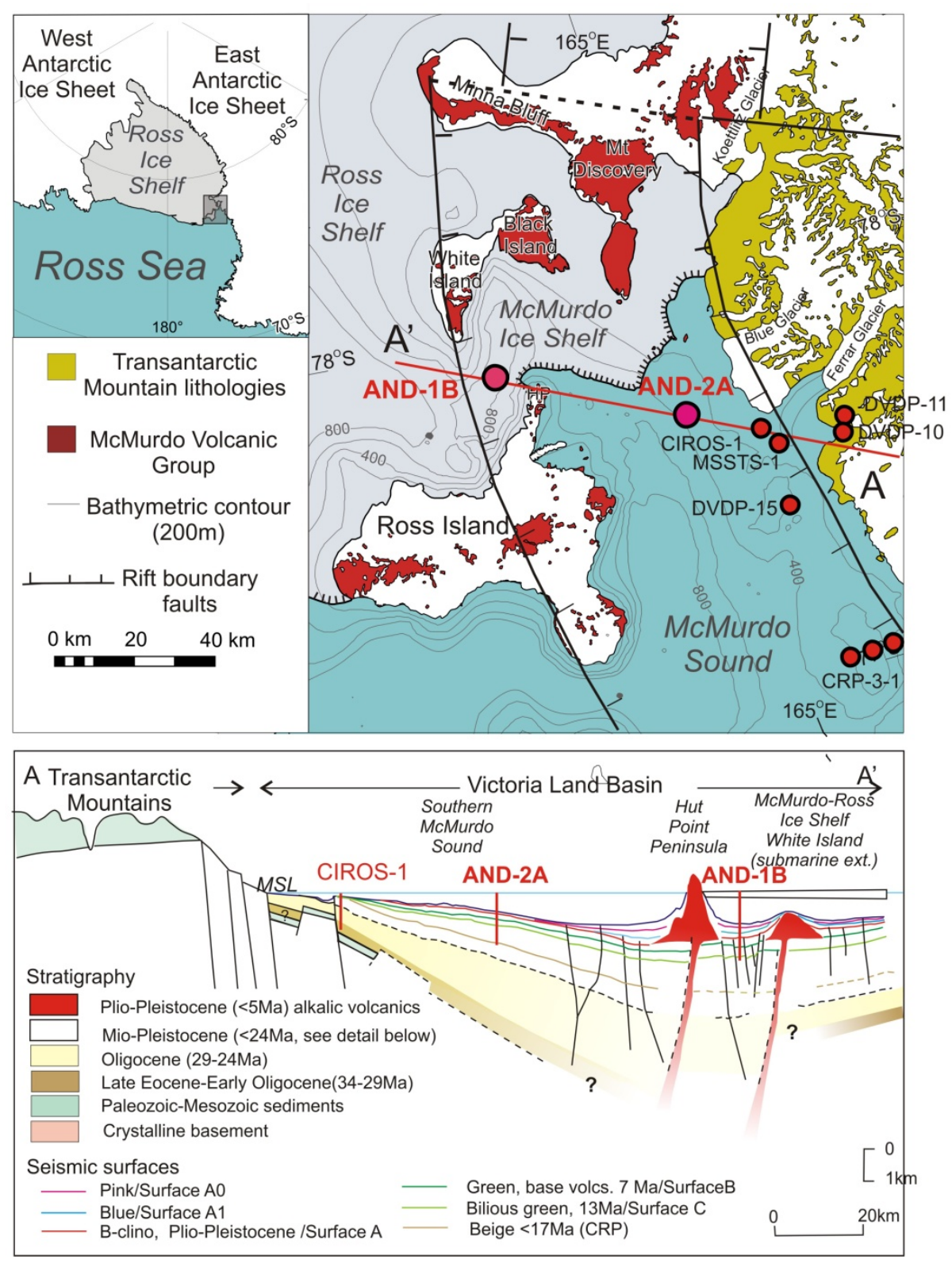

Figure S1. Location of sea-ice and ice-shelf based geological drill core records from the Victoria Land Basin (VLB) in McMurdo Sound. Geological cross-section (A-A') across the VLB shows the stratigraphic relationships and age of strata recovered by the AND-1B core. 

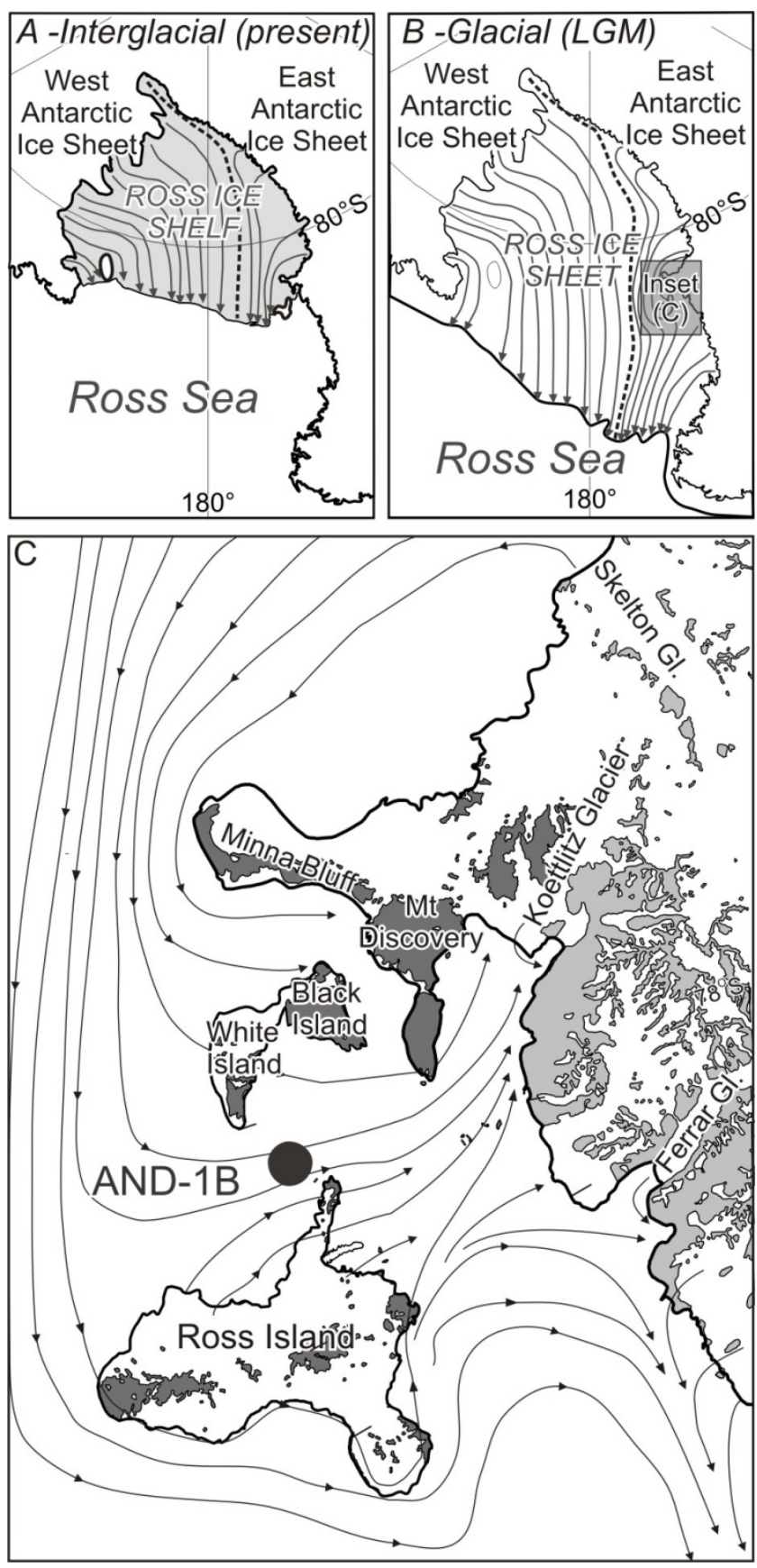

Figure S2. Flow line reconstructions for (A) Holocene ${ }^{51}$ and (B) LGM $^{53}$ ice sheet/ice shelf configurations in the Ross Embayment, and $(C)$ regional ice flow reconstructed for McMurdo Sound during the $\mathrm{LGM}^{52}$. 


\section{MOTIF 2b - DIAMICTITE/DIATOMITE CYCLES}

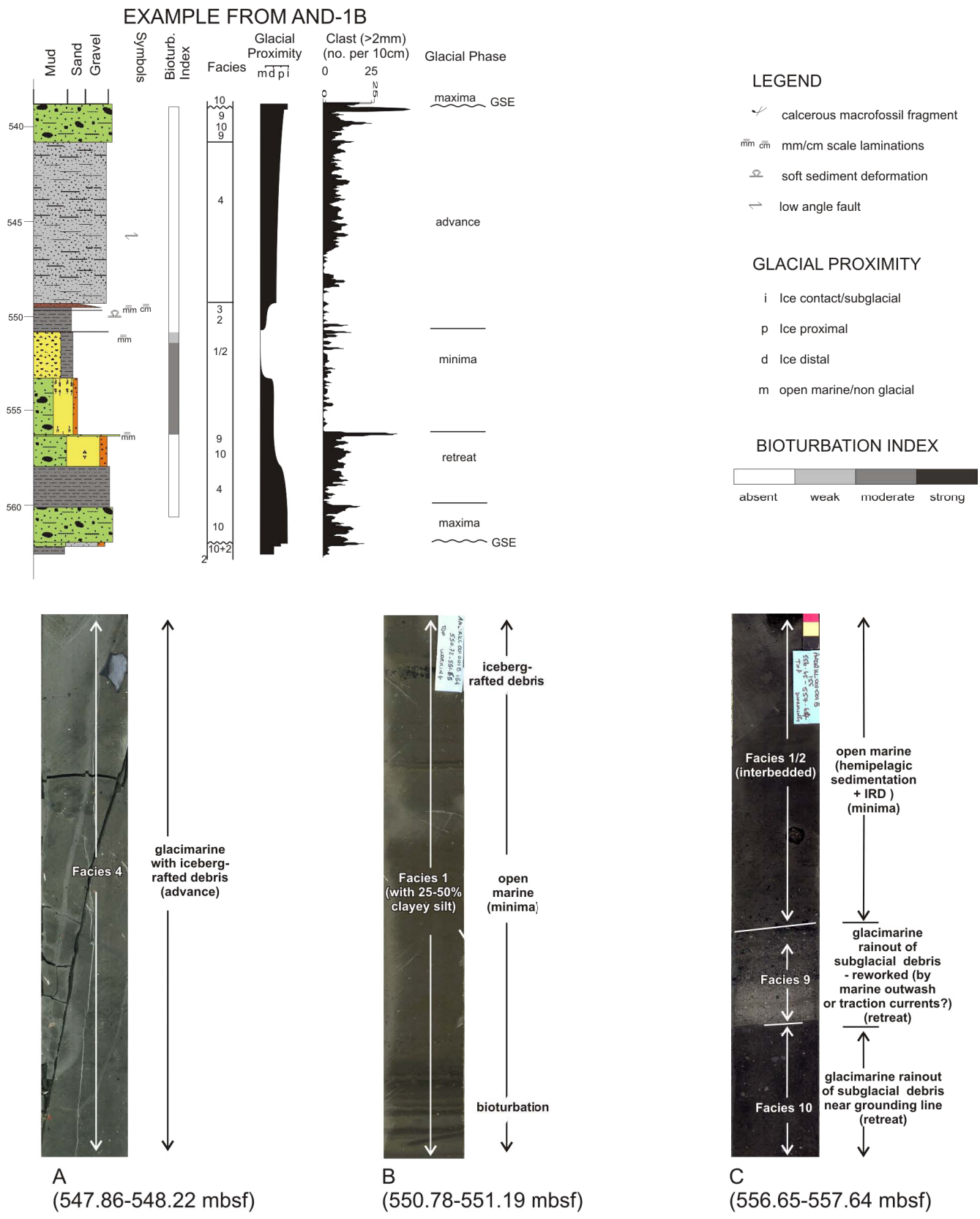

Figure S3 Detailed sedimentological analysis and interpretation of Early Pliocene Cycle 39. An example of a Motif 2B style of subpolar deposition during a $40 \mathrm{kyr}$ cycle of grounding line advance followed by retreat to open ice free oceanic condition and readvance. Facies are summarised in Fig. S2. 


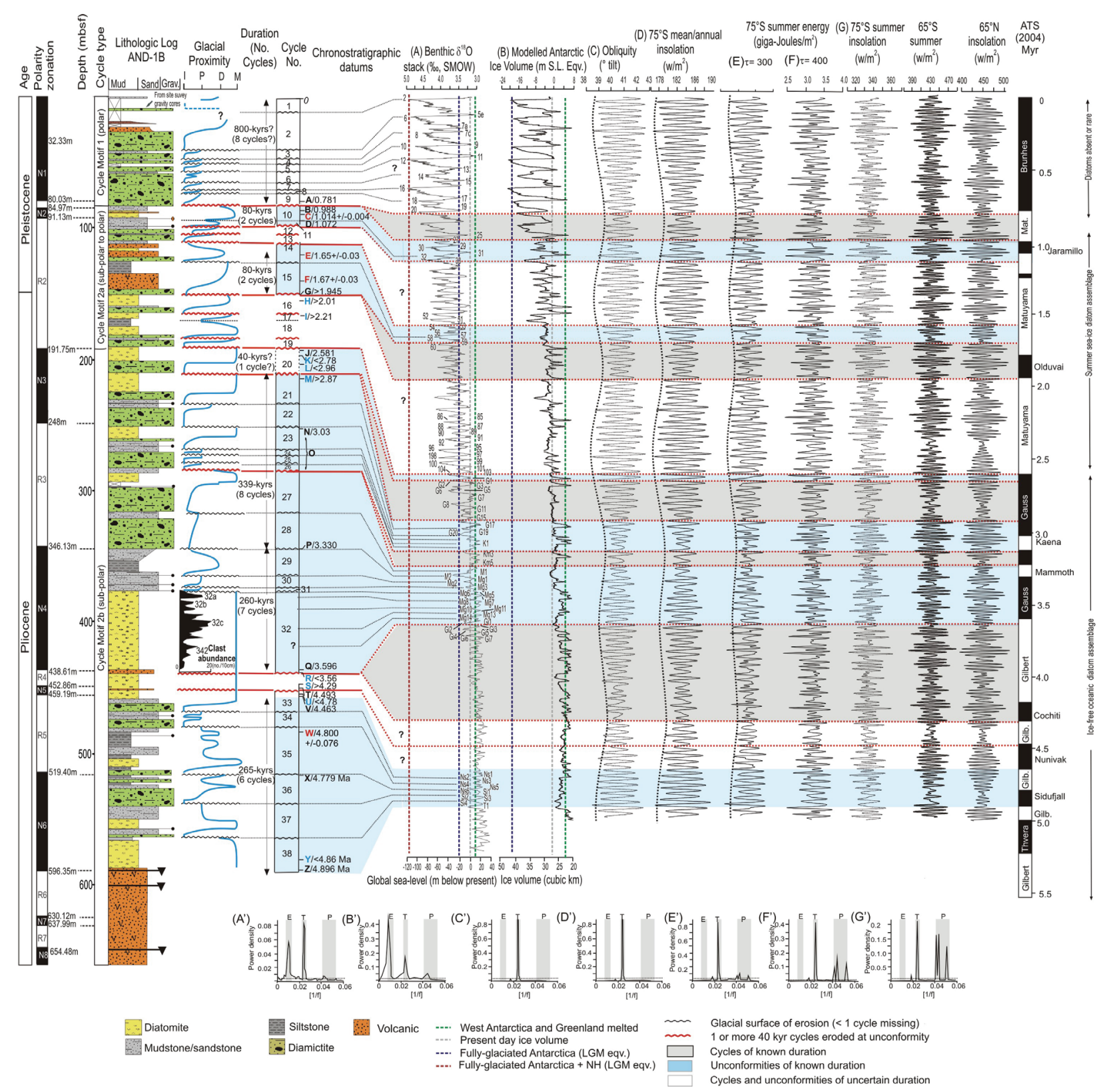

Figure S4. (Expands on Fig. 2) Stratigraphic and chronologic summary of the upper 600m of the AND-1B core showing 40 sedimentary cylces of ice advance-retreat-readvance during the last 5 myrs. Lithologies (rock-types) that comprise the cycles are plotted against depth. Glacial proximity curve tracks the relative position of the grounding line through (i) ice-contact, (p) ice-proximal, (d) ice-distal and $(\mathrm{m})$ marine environments within cycles and provides a proxy for ice extent. Cycle duration is constrained by chronostratigraphic datums coded A-Z and explained in Table S1, and allows correlation of certain intervals of the core with time series of (A) stacked benthic $\delta^{18} \mathrm{O}$ record ${ }^{25}$, (B) model Antarctic ice volume ${ }^{7}$ (C) obliquity, (D) mean annual insolation at $75^{\circ} \mathrm{S},(\mathrm{E})$ summer energy at $75^{\circ} \mathrm{S}$ for inferred melt-threshold $(\tau)$ of $300 \mathrm{Wm}^{-2}$ and $(\mathrm{F}) 400 \mathrm{Wm} \mathrm{m}^{-2}$, and (G) summer insolation at $75^{\circ} \mathrm{S}$. Summer insolation at $65^{\circ} \mathrm{S}$ and $65^{\circ} \mathrm{N}$ are also shown.

Spectral estimates show that the majority of the variability is in the obliquity band for $\left(A^{\prime}\right) \delta^{18} O$ record, ( $\left.D^{\prime}\right)$ mean annual insolation, and $\left(E^{\prime}\right)$ summer energy at $75^{\circ} \mathrm{S}\left(\tau=300 \mathrm{Wm}^{-2}\right)$. At a summer melt threshold of $\tau=400 \mathrm{Wm}^{-2},\left(F^{\prime}\right)$ the variability contains a strong 20,000 year periodicity implying that a colder Pleistocene Antarctic ice sheet system might respond to summer duration at the precessional band ${ }^{31}$. The relative increase in $100 \mathrm{kyr}$ power in $\left(\mathrm{B}^{\prime}\right)$ model Antarctic ice volume reflects the increased influence of large $\mathrm{NH}$ ice sheets and associated glacio-eustatic fluctuations in the Late Pleistocene. $E=e c c e n t r i c i t y$ or 100 kyrs, $\mathrm{T}=$ tilt or obliquity, $\mathrm{P}=$ precession. The notation $\delta^{18} \mathrm{O}$ is a measure of the abundance of the ${ }^{18} \mathrm{O}$ isotope relative to mean ocean water (SMOW). 
Age-Probability Diagram for 481.80-MS (481.80 mbsf)

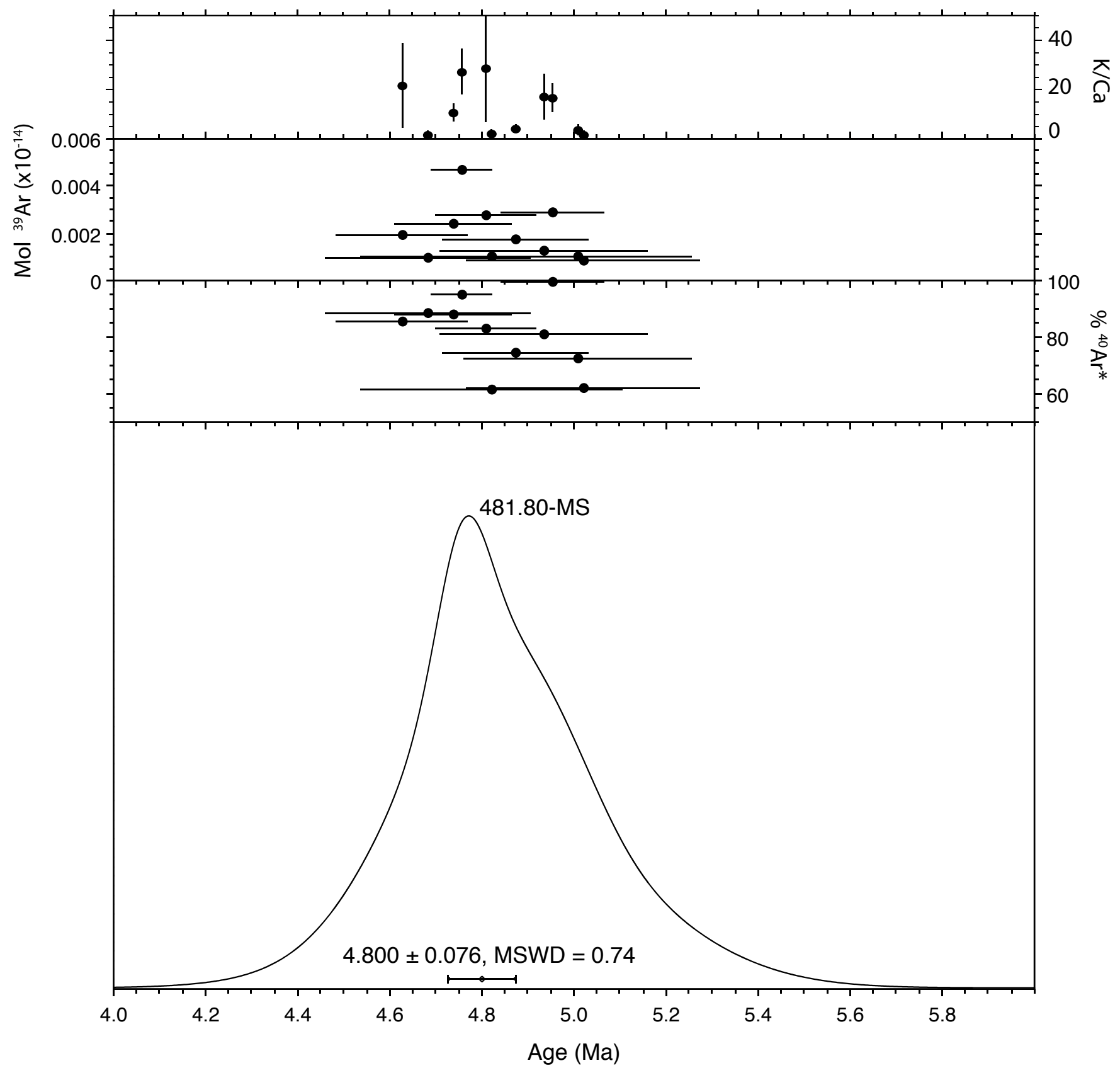

Figure S5. Age-probability diagram for sample 481.80 mbsf showing 11 of the 14 feldspar grains analyzed. Error bars represent $2 \sigma$ error. Mean standard weighted deviation (MSDW) is also reported to $2 \sigma$. 


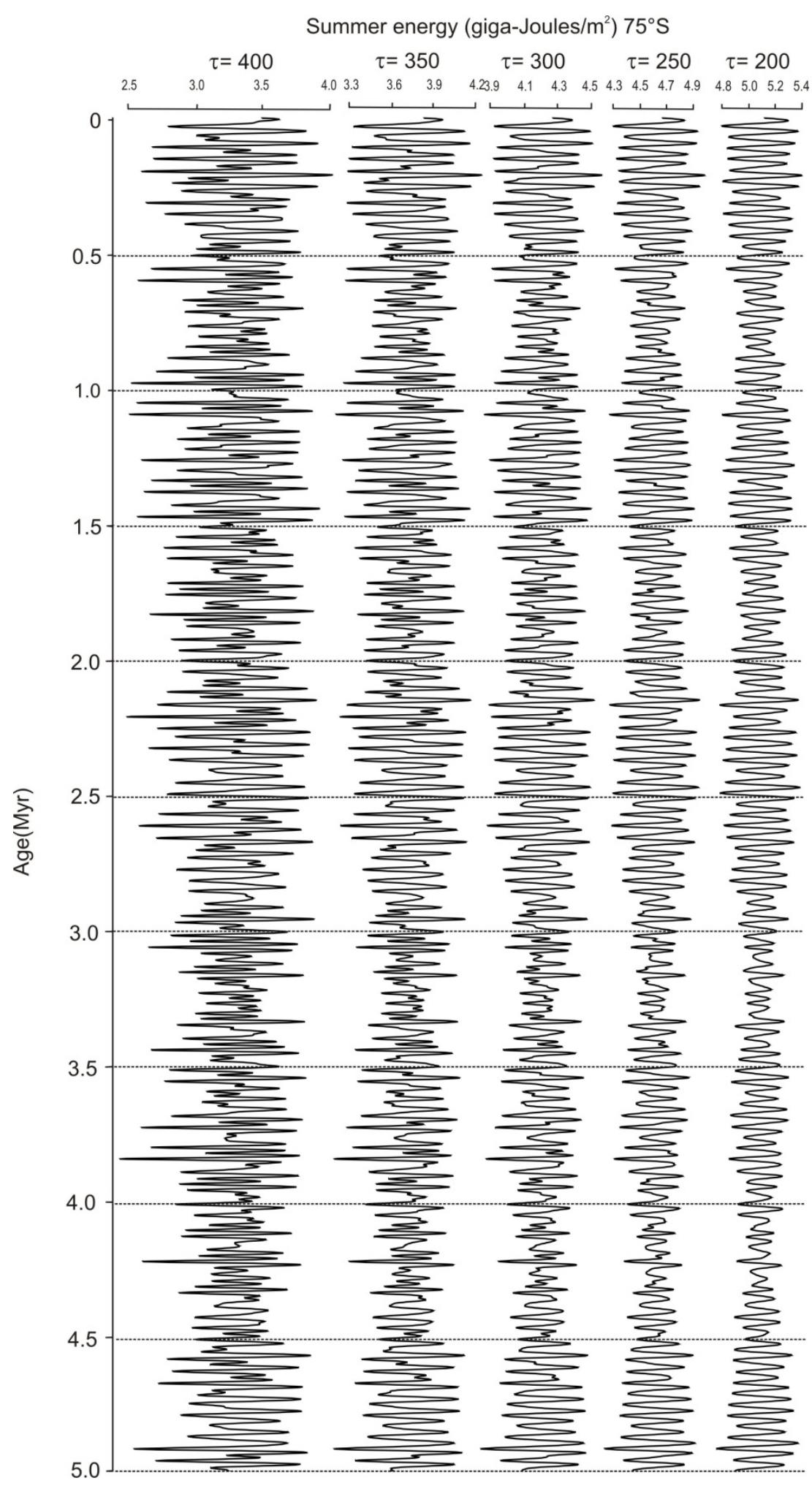

Figure S6. Summer energy at $75^{\circ} \mathrm{S}$ computed using increasingly higher thresholds (from right to left) following the approach of Huybers ${ }^{8}$. 
Table S1. Chronostratigraphic constraints for AND-1B

\begin{tabular}{|c|c|c|c|c|c|}
\hline Datum & Depth (mbsf) & Type & Age(Myr) & Error $( \pm)$ & Comment \\
\hline A & 80.03 & paleomagnetic & 0.781 & & Bruhnes-Matuyama transition† \\
\hline B & 84.97 & paleomagnetic & 0.988 & & top Jaramillo Subchron† \\
\hline C & 85.50 & radiometric & 1.014 & 0.004 & ${ }^{40} \mathrm{Ar} /{ }^{39} \mathrm{Ar}, \mathrm{K}-\mathrm{feldspar} \ddagger$ \\
\hline D & 91.13 & paleomagnetic & 1.072 & & base Jaramillo Subchront \\
\hline$E$ & 112.51 & radiometric & 1.65 & 0.03 & ${ }^{40} \mathrm{Ar} /{ }^{39} \mathrm{Ar}$, basaltic glass $\ddagger$ \\
\hline $\mathrm{F}$ & 136.21 & radiometric & 1.67 & 0.03 & ${ }^{40} \mathrm{Ar} /{ }^{39} \mathrm{Ar}$, basaltic glass $\ddagger$ \\
\hline G & 150.73 & paleomagnetic & $\geq 1.945$ & & absence of Olduvai Subchron \\
\hline $\mathrm{H}$ & 158.9 & biostratigraphic & $\geq 2.01$ & & LO of Actinocyclus fasciculata \\
\hline I & 164.1 & biostratigraphic & $\geq 2.21$ & & LO of Actinocyclus maccollumii \\
\hline J & 191.75 & paleomagnetic & 2.581 & & Gauss-Matuyama transition† \\
\hline K & 193.7 & biostratigraphic & $\leq 2.79$ & & FO of $A$. fasciculata \\
\hline $\mathrm{L}$ & 201.4 & biostratigraphic & $\leq 2.87$ & & FO of $A$. maccollumii \\
\hline M & 212 & & $\geq 2.87$ & & $\begin{array}{l}\text { absence of } A \text {. fasciculata and } A \text {. } \\
\text { maccollumii }\end{array}$ \\
\hline $\mathrm{N}$ & 248.00 & paleomagnetic & 3.032 & & Top Kaena Subchront \\
\hline $\mathrm{O}$ & $267.28-282.83$ & paleomagnetic & $\begin{array}{l}3.032 \\
-3.116\end{array}$ & & $\begin{array}{l}4 \text { cycles within Kaena Subchron } \\
\text { (112.8-myr-duartion) }{ }^{\dagger}\end{array}$ \\
\hline$P$ & 346.13 & paleomagnetic & 3.330 & & base of Mammoth Subchront \\
\hline Q & 438.61 & paleomagnetic & 3.596 & & Gilbert-Gauss transition† \\
\hline $\mathrm{R}$ & 440.12 & biostratigraphic & $\leq 3.56$ & & FO of Rhizosolenia sp. D * \\
\hline S & $440.12-450$ & biostratigraphic & $\begin{array}{l}\geq 4.29 \\
4.72\end{array}$ & & $\begin{array}{l}\text { absence of F.interfrigidaria and } F \text {. } \\
\text { barronii }\end{array}$ \\
\hline $\mathrm{T}$ & 452.86 & paleomagnetic & 4.493 & & Top Nunivak Subchron† \\
\hline$U$ & 456.00 & biostratigraphic & $\leq 4.78$ & & FO of T. striata \\
\hline V & 459.19 & paleomagnetic & 4.631 & & Base Nunivak Subchron† \\
\hline W & 481.80 & radiometric & 4.800 & 0.076 & ${ }^{40} \mathrm{Ar} /{ }^{39} \mathrm{Ar}$, K-feldspar $\ddagger \ddagger$ \\
\hline$X$ & 519.40 & paleomagnetic & 4.799 & & Top Sidufjall Subchron† \\
\hline Y & 583.64 & biostratigraphic & $\leq 4.86$ & & FO of T. complicata* \\
\hline Z & 596.35 & paleomagnetic & 4.896 & & Base Sidufjall Subchron† \\
\hline
\end{tabular}

+ based on geomagnetic polarity timescale calibration of Ogg \& Smith $^{62}, \neq$ from Wilson et al. ${ }^{63}$, biostratigraphic event ages include the maximum and minimum age identified in the CONOP-constrained Southern Ocean diatom biochronologic calibration of Cody et al. ${ }^{40}$, ${ }^{*}$ except which are new (unpublished) ages determined in recent model runs (Cody et al., submitted), ¥¥ see Supplementary Information (below). 
Table S2. Lithofacies, interpretation of depositional process and glacimarine environment for AND-1B

\begin{tabular}{|c|c|c|}
\hline Facies number and name & Predominant process interpretation & Glacimarine depositional environment \\
\hline 1 - Diatomite & $\begin{array}{l}\text { Pelagic rain }+/ \text { - hemipelagic suspension } \\
\text { settling (low terrigenous Input) }\end{array}$ & $\begin{array}{l}\text { Open marine Ross Embayment, with or } \\
\text { without ice berg rafting }\end{array}$ \\
\hline 2 - Mudstone & $\begin{array}{l}\text { Hemipelagic suspension settling } \\
\text { (high terrigenous input) }\end{array}$ & $\begin{array}{l}\text { Open marine Ross Embayment, with or } \\
\text { without ice berg rafting }\end{array}$ \\
\hline $\begin{array}{l}3 \text { - Interstratified } \\
\text { mudstone and sandstone }\end{array}$ & $\begin{array}{l}\text { Low to moderate density sediment } \\
\text { gravity flow } \\
\text { Hemipelagic suspension settling +/-IBRD } \\
\text { Redeposition by marine outwash }\end{array}$ & Distal grounding zone, grounding line fan \\
\hline $\begin{array}{l}4 \text { - Mudstone with } \\
\text { dispersed/common clasts }\end{array}$ & $\begin{array}{l}\text { Subglacial deposition } \\
\text { Hemipelagic suspension settling } \\
\text { Rainout from ice rafting }\end{array}$ & Proximal to distal grounding zone (polar) \\
\hline $\begin{array}{l}5 \text { - Rhythmically } \\
\text { interlaminated mudstone } \\
\text { with siltstone or sandstone }\end{array}$ & $\begin{array}{l}\text { Suspension settling from turbid plumes } \\
\text { Low-density turbidity current deposition } \\
\text { Rainout from ice rafting }\end{array}$ & $\begin{array}{l}\text { Proximal to distal grounding zone (sub- } \\
\text { polar) }\end{array}$ \\
\hline 6 - Sandstone & Sediment gravity flows, fluvial outwash & $\begin{array}{l}\text { Proximal grounding zone, grounding line } \\
\text { fan }\end{array}$ \\
\hline 7 - Conglomerate & $\begin{array}{l}\text { Redeposition by marine outwash } \\
\text { Redeposition by mass flow }\end{array}$ & $\begin{array}{l}\text { Proximal grounding zone, grounding line } \\
\text { fan }\end{array}$ \\
\hline 8 - Breccia & $\begin{array}{l}\text { Sediment redeposition by mass flow. } \\
\text { Volcanic debris flow. }\end{array}$ & $\begin{array}{l}\text { Proximal grounding zone, grounding line } \\
\text { fan }\end{array}$ \\
\hline 9 - Stratified diamictite & $\begin{array}{l}\text { Subglacial deposition } \\
\text { Rainout with currents } \\
\text { Debris flow depositon }\end{array}$ & Subglacial to proximal grounding zone \\
\hline 10 - Massive diamictite & $\begin{array}{l}\text { Subglacial deposition } \\
\text { Rainout without currents } \\
\text { Debris flow depositon }\end{array}$ & Subglacial to proximal grounding zone \\
\hline 11 - Volcanic sediments & $\begin{array}{l}\text { Primary volcanics deposits/volcanic } \\
\text { debris }\end{array}$ & Subglacial to open marine \\
\hline
\end{tabular}




\section{Supplementary Discussion}

\section{Geological setting of AND-1B drillcore}

Ross Island lies at the southern end of the Victoria Land Basin (VLB), an 350-km-long half-graben, hinged on its western side at the Transantarctic Mountain (TAM) front (Fig. S1). Major rifting in the VLB has occurred since the latest Eocene, perhaps having been initiated in the Cretaceous ${ }^{44,45}$, and has accommodated up to $10 \mathrm{~km}$ of sediment fill. A new rift history, based on the Cape Roberts Project (predecessor to ANDRILL) drill cores linked to a new regional seismic stratigraphic framework ${ }^{46,47}$ indicates that crustal stretching during the Oligocene syn-rift phase produced rapid subsidence, followed by thermally-controlled slower subsidence in the Early Miocene. Renewed rifting within the centre of the VLB beginning in the Late Miocene has continued through to present day. This forms the Terror $\mathrm{Rift}^{48}$, and is associated with alkalic igneous intrusions and extrusive volcanism (e.g. Beaufort Island and Ross Island). Quaternary loading of the crust by the Ross Island volcanoes has added significantly to subsidence near Ross Island, and the development of an enclosing moat ${ }^{49}$. The Terror Rift has accommodated up to $3 \mathrm{~km}$ of Neogene sediment beneath Windless Bight. Here, the load-induced subsidence caused by Ross Island has contributed significantly to the generation of accommodation space, especially during the last $2 \mathrm{myr}^{50}$. Neogene strata have now been extensively mapped in southern McMurdo Sound from the Drygalski Ice Tongue south to Ross Island. These Neogene strata show a thickening and eastward-dipping succession extending under Ross Island in the vicinity of the AND-1B drillsite.

\section{Glaciological setting of AND-1B drillcore}

AND-1B was drilled at Windless Bight beneath the McMurdo Ice Shelf (Fig. S1) that is an extension of the Ross Ice Shelf at its northwest margin. The McMurdo Ice Shelf has a surface snow accumulation of $\sim 0.3 \mathrm{my}^{-1}$, and the present day calving line is $\sim 5 \mathrm{~km}$ north from the drillsite. Basal melting of the ice shelf is currently occurring at the AND-1B drill site, but the ice is likely free of sediment ${ }^{27}$. The Ross Ice Shelf itself is a major component of the WAIS system with approximately two-thirds of the ice shelf being nourished by ice streams that drain the WAIS, while its western margin is fed by EAIS outlet glaciers ${ }^{51}$ (Fig. S2). Reconstructions of grounded ice expansion within the Ross Embayment during the Last Glacial Maximum (LGM) ${ }^{52}$ indicate an ice sheet that extended to near the edge of the continental shelf and was fed by a contribution from both East and West Antarctic ${ }^{53}$ (Fig. S2).

We have interpreted the glacimarine cycles in AND-1B as documenting retreat and advance of a large marine-based, ice sheet within the Ross Embayment. This ice sheet was/is susceptible to large variations in spatial extent through glacial/interglacial cycles ${ }^{7}$. The provenance of clasts within subglacially deposited diamictites in the AND-1B record are consistent with transport by glacial ice sourced from EAIS outlet glaciers to the south of the drill site ${ }^{22}$, indicating that grounded ice events in AND-1B were the result of a large scale advance of the ice sheet across the Ross Embayment, rather than localised glacial advance from Ross Island or outlet glaciers in the McMurdo Sound region.

The ice sheet that occupied the Ross Embayment during past glacial maxima was separated from the high-elevation, land-based sector of the EAIS by the TAM (Fig. S1), and therefore had significantly different mass balance controls and responses to past warm periods. Subglacial sediments in AND-1B were deposited by an ice sheet that was grounded well below sea level. The marine-based ice sheet was highly responsive to oceanic-related mass balance controls, such as eustasy and ocean-induced melting. Model results support this conclusion ${ }^{7}$. Of importance in the model, with regard to ice sheet retreat 
within the greater Ross Embayment (including sections of the presently-grounded WAIS), is that marine ice sheet grounding lines are inherently unstable on reverse bed-slopes ${ }^{\text {e.g.54 }}$. This combined with other forcings such as rising sea-levels, an increased ice sheet temperature profile and/or basal slipperiness is shown to result in rapid, and irreversible retreat. Once retreat was initiated for past configurations of the ice sheet in the Ross Embayment, it was likely to occur across the entire embayment, similar to the pattern of retreat documented for the last deglaciation ${ }^{\text {e.g52,53,54-56. }}$.

Within the McMurdo Sound region, topographic roughness and potential pinning points are provided by the island volcanoes of the Erebus Volcanic Province. Although not fully resolved due to the spatial resolution of the ice sheet model $\left(10 \mathrm{~km}^{2}\right)$, their influence appears to be relatively minor in comparison to that of ocean warming and eustasy during Pliocene-Pleistocene glacial terminations ${ }^{7}$. Local pinning may delay the eventual collapse/retreat of the ice shelf/ice sheet by a few thousand years during orbital-scale climate cycles. The volcanic edifices of Minna Bluff, Mt Discovery, White Island, Black Island and Ross Island have expressed significant topographic relief above sea level, during the last 5 myr. For example, temporal variations in volcanic activity such as Mt Erebus cone-building ${ }^{57}$ are not considered to have fundamentally changed the influence of topographic pinning within the last 1 myr.

\section{Cycle facies motifs and the interpretation of ice sheet thermal regime from AND-1B drillcore}

Three distinctive styles of stratigraphic architecture termed "cycle-motifs" have been identified within the entire length of the AND-1B core, and are associated with glacimarine deposition under different thermal regimes of the ice sheet during the last $13.5 \mathrm{myr}^{22}$. Two of the cycle motifs occur in the Pliocene-Pleistocene interval.

1. Polar-type cycles (Motif 1) are dominated by diamictite facies of subglacial and ice-proximal affinity, lack evidence of any significant subglacial meltwater or erosion, and are considered to form under cold, polar conditions with little to no channelised meltwater discharging from the grounding line. This style of depositional cycle provides a stratigraphic signature of advance and retreat of an extensive ice sheet/ice shelf system in the Ross Embayment, similar to Last Glacial Maximum (LGM) to Holocene sedimentary sequences known from the Ross Sea and from beneath the McMurdo Ice Shelf .

2. Subpolar-type cycles (Motif 2) contain thick (up to $20 \mathrm{~m}$ ) intervals of diatomite representing ice free-marine conditions during interglacials. They are divided into two subgroups based on the degree of glacimarine meltwater deposits at the transitions between diamictite and diatomite. Motif 2A cycles (lower meltwater volume) display relatively abrupt transitions between grounding-line proximal deposits and open-marine biogenic sediments as represented by thick deposits of diatomite, with only minor terrigenous content $(<10 \%)$. They imply relatively rapid retreat of the WAIS. Thermal conditions of the ice sheet are interpreted as polar to subpolar, warmer than present, yet with limited submarine meltwater and terrigenous sediment supply. Motif 2B cycles typically display a 5- to 10-m-thick terrigenous, glacimarine retreat succession, up to an order of magnitude thicker than in Motif 2A cycles. Similar types of subpolar glacimarine sequences associated with a range of relatively, high meltwater volumes have been described for LGM and Holocene sediments along the marine margin of Greenland . 
The vertical stacking of cycle motif types is illustrated in Fig. S2 and shows an up-core transition that represents the gradual cooling of the ice sheet, implied by progressively lower volumes of meltwater. Although this is not the primary focus of this paper, evidence for the latter is outlined in a related paper $^{21}$. Here we note on the basis of the characteristics of the grounding-zone facies, and by comparison with modern glacial environments, a reduction of meltwater representing climate cooling and a transition from a subpolar to a polar ice sheet occurs in the AND-1B core $~ 200$ mbsf at the level of the Gauss-Matuyama polarity transition (2.6 Myr).

\section{Argon geochronology at $481.80 \mathrm{mbsf}$.}

Potassium-feldspar grains from a pumice-rich mudstone interval were separated and analyzed using the ${ }^{40} \mathrm{Ar} /{ }^{39} \mathrm{Ar}$ method and Single Crystal Laser Fusion technique. The feldspar grains were separated from the pumice-rich layer by crushing and sieving, followed by air abrasion and ultrasonic cleaning to remove any adhering matrix, and lastly handpicked using a binocular microscope to obtain a monomineralic separate. The sample grains were loaded into Al irradiation discs in a known geometry with Fish Canyon Tuff (FC-2) neutron flux monitors (28.02 Myr). The sample irradiation package (NM214) was irradiated for 1-hour at Texas A\&M Nuclear Science Center, College Station, TX. All ${ }^{40} \mathrm{Ar} /{ }^{39} \mathrm{Ar}$ analyses were conducted at the New Mexico Geochronology Research Laboratory, Socorro, with an automated all-metal UHV extraction line and MAP-215-50 Mass Spectrometer. Samples and flux monitors were fused by a 50 watt Synrad $\mathrm{CO}_{2}$ laser. Reactive gases were isolated from the sample gas during a 2 minute reaction period with two SAES GP-50 getters, one operated at $\sim 450^{\circ} \mathrm{C}$ and the other at $20^{\circ} \mathrm{C}$. Sample gas was also exposed to a $W$ filament operated at $\sim 2000^{\circ} \mathrm{C}$ and a cold finger operated at $140^{\circ} \mathrm{C}$ for addition gas clean-up. Total system blank and backgrounds for laser analyses averaged 56 , $1.2,0.5,5.3,0.7 \times 10^{-18}$ moles for masses $40,39,38,37,36$, respectively. Electron multiplier sensitivity averaged $4.95 \times 10^{-17} \mathrm{~mol} / \mathrm{pA}$ for all laser analyses.

When plotted on an age-probability diagram, 11 of the 14 single crystal sanidine and anorthoclase analyses yield a high precision mean age of $4.800 \pm 0.076 \mathrm{Myr}$ ( $2 \sigma$ error) (Fig. S5). The mean age is statistically robust, indicated by a unimodal normal distribution of ages and a mean square weighted deviation close to unity (MSWD $=0.74$ ). Analyses 481.80-01-2, 9 and 14 are statistical outliers omitted from mean age calculations. Analysis 481.80-01-2 yields a statistically younger age than the mean. In addition, both the relatively low radiogenic yield (53.4\%) and $\mathrm{K} / \mathrm{Ca}(0.79)$ suggests $481.80-01-2$ represents a low potassium or altered grain. Analysis 481.80-01-9 yields an older age than the mean, but a similar radiogenic yield and $\mathrm{K} / \mathrm{Ca}$. We infer this analysis to represent an older inherited grain. Analysis 481.80-01-14 has an anomalously low ${ }^{39} \mathrm{Ar}_{\mathrm{K}}$ signal $\left(0.006 \times 10^{-15} \mathrm{~mol}\right)$ and old age $(221.6 \pm 52.4$ Myr, $2 \sigma$ error). This analysis represents a low potassium, high calcium grain $(K / C a=2.7)$ and is likely a xenocryst. The $\mathrm{K} / \mathrm{Ca}$ values for all analyses used in the mean age calculation exhibit significant variability, ranging from 1.1 to 28.5. This variability in $\mathrm{K} / \mathrm{Ca}$, however, does not exceed typical anorthoclase-sanidine ratios and can be accounted for by the analysis of: 1) a zoned feldspar fragmented upon eruption, 2) feldspars from a chemically zoned magma chamber, or 3) material deposited following a vent clearing eruption.

\section{Pliocene summer energy, melt-thresholds and insolation intensity}

A further impact of obliquity on high-latitude insolation derives from Kepler's $2^{\text {nd }}$ law, where Earth's distance from the sun is inversely proportional to its angular velocity. Summers with the greatest 
insolation intensity, that occur when Earth's orbit is in perihelion at the solstice, are also the shortest due to increased angular velocity, implying that ice sheet ablation may be more sensitive to insolation integrated over the length of the summer (summer energy), than its peak intensity ${ }^{8}$. Fig. S6 shows summer energy at $75^{\circ} \mathrm{S}$ calculated using different melt-thresholds $(\tau)$ following the approach of Huybers ${ }^{8}$. For thresholds of less than $250 \mathrm{Wm}^{-2}$ summer energy varies almost exclusively at the obliquity period. Higher thresholds give greater variability at precession periods as well as greater overall variability. The majority of the variability is at the obliquity period until $\tau$ is greater than $340 \mathrm{Wm}^{-2}$, when precession and obliquity period variance are equal. A warmer-than-present Pliocene climate with minimal sea ice cover in Ross Embayment for the majority of the summer is implied by the diatom assemblage, and suggests an extended period of positive degree-days. For Pliocene southern highlatitudes, the temperature may have been near $0^{\circ} \mathrm{C}$ when insolation intensity was around $300 \mathrm{Wm}^{-2}$. This melt-threshold presently occurs between $40^{\circ}-70^{\circ} \mathrm{N}^{8}$. Fig. S4 expands upon Fig. 2 and shows correlation of the $40 \mathrm{kyr}$ duration, AND-1B cycles with summer energy curves calculated for $\tau=300 \mathrm{Wm}^{-2}$ and $400 \mathrm{Wm}^{-2}$ as well as mean annual insolation for the last $5 \mathrm{myr}$ (also shown in detail for chronostratigraphically well-constrained intervals of the core in Figs. $3 \& 4$ ).

Summer solstice, insolation intensity for both $65^{\circ} \mathrm{N}$ and $65^{\circ} \mathrm{S}$ is also plotted in Fig. S4. Seasonal insolation has been proposed to influence Antarctic ice sheet system, both in terms of its intensity ${ }^{58}$ and duration $^{59}$. An uncommon orbital configuration produced an extended period of high Antarctic insolation values and warm summers during mid-Pleistocene interglacial MIS 31 ( 1 Myr). Geological evidence for ice-free marine conditions in Ross Embayment at this time, together with summer seasurface temperatures $2-4^{\circ} \mathrm{C}$ higher than present was recorded in the sediments of Cape Roberts Project (CRP) cores $^{33}$. The age constraints for the CRP record imply warming driven by southern insolation and Antarctic melt prior to the $\mathrm{NH}$ insolation maximum. While we do not dispute the role of seasonal insolation intensity on polar ice volume, especially during times of high eccentricity, our data from the Pliocene AND-1B core (prior to the onset of bipolar glaciations) and the fundamental influence of oceaninduced melting ${ }^{7}$ favours the role of mean annual insolation with an additional influence of summer energy, both paced by obliquity, as the first order astronomical control on Antarctic ice volume. 


\section{Supplementary Notes: Additional References}

44. Cooper, A.K. \& Davey, F.J. Episodic Rifting of the Phanerozoic rocks of the Victoria Land basin, western Ross Sea. Antarctica Science, 229, 1085-1087 (1985).

45. Brancolini, G., et al., Descriptive text for the seismic stratigraphic atlas of the Ross Sea, Antarctica, in Geology and Seismic Stratigraphy of the Antarctic Margin, Antarctic Research. Series, 68, edited by Cooper, A.K., Barker, P. \& Brancolini, G. 271-286, AGU, Washington (1995).

46. Fielding, C.F., Whittaker. J, Henrys, S., Wilson, T \& Naish, T.R. Seismic facies and stratigraphy of the Cenozoic succession in McMurdo Sound, Antarctica: implications for tectonic, climatic and glacial history. Palaeogeography, Palaeoclimatology, Palaeoecology, 260, 245-261 (2008).

47. Henrys, S.A., Wilson, T.J. Whittaker, J.M., Fielding, C.R., Hall, J.M. \& Naish, T.R. Tectonic history of mid-Miocene to present southern Victoria Land Basin, inferred from seismic stratigraphy in McMurdo Sound, Antarctica, in Antarctica: A Keystone in a Changing World - Online Proceedings of the 10th ISAES, edited by Cooper, A.K. et al., USGS Open-File Report 2007-1047, Short Research Paper 049 (2007).

48. Cooper, A.K., Davey, F.J. \& Behrendt, J.C. Seismic stratigraphy and structure of the Victoria Land Basin, Western Ross Sea, Antarctica, in The Antarctic Continental Margin: Geology and Geophysics of the Western Ross Sea, edited by Cooper, A.K. \& Davey, F.J. 27-77, Circum-Pacific Council Energy Mineral Resources, Earth Sci. Ser., 5B, Houston, Texas (1987).

49. Stern, T.A., Davey, F.J. \&. Delisle, G. Lithospheric flexure induced by the load of the Ross Archipelago, southern Victoria Land, Antarctica, in Geological Evolution of Antarctica, edited by Thomson, R.R.A., Crame, A. \& Thomson, J.W., Cambridge University Press, Cambridge, UK, 323328 (1991).

50. Horgan, H., Naish, T., Bannister, S., Balfour, N. \& Wilson, G. Seismic stratigraphy of the Ross Island flexural moat under the McMurdo-Ross Ice Shelf, Antarctica, and a prognosis for stratigraphic drilling, Global Planetary Change, 45, 83-97 (2004).

51. Fahnestock, M.A., Scambos, T.A., Bindschadler, R.A. \& Kvaran, G. A millennium of variable ice flow recorded by the Ross Ice Shelf, Antarctica. Journal of Glaciology, 46, 652-664 (2000).

52. Denton, G.H. \& Hughes, T.J. Reconstructing the Antarctic Ice Sheet at the Last Glacial Maximum. Quaternary Science Reviews, 21, 193-202 (2002).

53. Licht, K.J., Dunbar, N.W., Andrews, J.T. \& Jennings, A.E. Distinguishing subglacial till and glacial marine diamictons in the western Ross Sea, Antarctica; implications for a last glacial maximum grounding line. Geological Society of America Bulletin, 111, 91-103 (1999).

54. Schoof, C. Ice sheet grounding line dynamics: steady states, stability and hysteresis. Journal of Geophysical Research, 112, F03S28, doi:10.1029/2006JF000664 (2007).

55. Shipp, S., Anderson, J.B. \& Domack, E.W. Late Pleistocene-Holocene retreat of the West Antarctic ice-sheet system in the Ross Sea; Part 1, Geophysical results. Geological Society of America Bulletin, 111, 1486-1516 (1999).

56. Conway, H., Hall, B.L., Denton, G.H., Gades, A.M. \& Waddington, E.D., Past and future grounding-line retreat of the West Antarctic Ice Sheet. Science, 286, 5438, 280-283 (1999).

57. Esser, R.E., Kyle, P.R. \& Mclntosh, W.C. ${ }^{40} \mathrm{Ar} /{ }^{39} \mathrm{Ar}$ dating of the eruptive history of Mount Erebus, Antarctica: volcano evolution. Bulletin of Volcanology, 66, 671-686 (2004).

58. Kawamura, K. et al. Northern Hemisphere forcing of climatic cycles in Antarctica over the past 360,000 years. Nature 448, 912-916 (2007).

59. Denton, G. \& Huybers, P. Antarctic temperature at orbital timescales controlled by local summer duration. Nature Geosciences, doi:10.1038/ngeo311 (2008).

60. Ogg, J.G. \& Smith, A.G. The geomagnetic polarity timescale. In A Geological Time Scale, Cambridge University Press, Cambridge UK, 63-95, edited by Gradstein et al. (2004). 
61. Wilson G., Levy R., Browne G., Dunbar, N., Florindo F., Henrys S., Graham I., Mclntosh W., McKay R., Naish T., Ohneiser C., Powell R., Ross J., Sagnotti L., Scherer R., Sjunneskog C., Strong C.P., Taviani M., Winter D. \& the ANDRILL-MIS Science Team. Preliminary Integrated chronostratigraphy of the AND-1B Core, ANDRILL McMurdo Ice Shelf Project, Antarctica. Terra Antartica, 14, 297-316 (2007). 